\title{
Chapter 9: The paradoxes of democracy and the rule of law
}

Coordinating Lead Authors: ${ }^{1}$ Donatella della Porta, Michael Keating

Lead Authors: ${ }^{2}$ Gianpaolo Baiocchi, Colin Crouch, Donatella della Porta, Sheila Jasanoff, Michael Keating, Erika Kraemer-Mbula, Dina Kiwan, Abby Peterson, Kenneth M. Roberts, Philippe C. Schmitter, Alberto Vannucci, Antoine Vauchez, Asanga Welikala.

\section{Summary}

The promise of modernization after the Second World War was that economic growth, equality, the rule of law and democracy would proceed together. In many ways, this has happened. Yet many of the promises of social progress developed after WWII have been undermined by internal tensions within the democratic project, as well as by social and economic trends. While stating the challenges that these trends have posed for democratic institutions and actors, we also look at the responses (both proposals and practices) that have emerged in order to address those challenges. In doing this, we note that the very conception of democracy as liberal democracy (based on delegation and majority voting) is under stress as neoliberalism has attacked those very intermediary institutions (parties, unions, voluntary associations) that had been at the basis of the development of the welfare state and democratic capitalism.

We start by noting the growth in inequality, which means that formal democracy is shaped by uneven power resources as concentration of wealth provides advantages in the capacity to influence public decision making with mutual convertibility of economic and

${ }^{1}$ Affiliations: Scuola Normale Superiore; University of Aberdeen.

${ }^{2}$ Affiliations: Scuola Normale Superiore; University of Aberdeen; University of Oxford; University of Pisa; University of Edinburgh; American University of Beirut; University of Johannesburg; Cornell University; New York University; University of Paris; Harvard University ; University of Gothenburg; European University Institute. 
political resources. The spiral of inequality and corporate political power is reflected in a growing legitimacy crisis in old and new democracies. Liberalism, which promised the separation between the state and the market, has evolved into neoliberalism, , based on the domination of the corporation, exacerbated by privatization and de-regulation. This has raised private profit criteria about considerations of the broader public good and in many cases encouraged corruption. The ensuing inefficiency and lack of transparency foster institutional mistrust, with perverse effects.

Challenges are also related to the fact that democracy has been mainly defined in a national mode, with the demos identified as the nation. Economic rescaling produced by global capitalism has however a produced both de-territorialization and re-territorialization, which requires a (yet unachieved) rethinking of the basis for democracy but also of welfare and its foundation in both identities and institutions. In the North and (with different characteristics) in the South of the globe, movement of capital and of people pose challenges of national pluralism and its constitutional recognition, questioning key concepts such as the definition of political community and popular sovereignty and the . relationship between human rights and citizenship. Citizenship is more appropriately considered as related not to fixed institutions but rather as 'acts of citizenships' requiring subjectivity and agency and more inclusive conceptions.

The main actors in democratic development have been affected by these challenges. Political parties are an important element in democracy but they have become an interest in their own right. A crisis of representation has emerged from growing social detachment of political parties from social cleavages as well as of elected representatives from the citizens. This had most dramatic effects on the Left, when left-wing parties have supported neoliberal reforms. Relying on expertise for the development of progressive policies is not a solution given the non-accountable power of science as well as the increasing challenges of 
privatization of knowledge-making, opacity of knowledge production and persistence of fundamental class imbalances in access to knowledge. Participatory channels of access to institutions have been opened to 'ordinary citizens' but, within neoliberalism, they are often based on individualist conceptions and do not address fundamental issues of inequalities. While citizens often call for direct participation, existing experiments rarely empower the citizens.

While the judiciary has been seen as a surrogate for democratic participation for marginalized minority groups, its capacity for rights enforcement is limited by the expansion (in particular at international level) of a lex mercatoria as well as the use of courts in order to protect economic freedom from democratic dynamics. The rule of law has also been subverted by unequal access to the law and by the influence of money while the judiciary also has its own particular interests and corporate lawyers assume a brokerage function in globalized markets. On the other hand, in the control of political dissent, the state, rather than being weakened from globalization, increases its reach and power. The 'war on terror' has been used to challenge the rule of law by states of emergency as well as authoritarian drifts with attempts at imposing a permanent 'state of exception'.

On the other hand, progressive social movements have addressed growing inequalities and democratic crises by developing alternative visions of democracy, stressing participation over delegation and deliberation over majoritarian decision-making. Participatory and deliberative conceptions have been prefigured as well as elaborated in recent waves of protests. The consolidation of oppositional actors, however, faces challenges in the fragmentation of the potential social bases, the need to build a new collective identity as well as to establish channels of access to power. This has resulted from, but also triggered, the reduction in citizens' entitlements and the weakening of the social contract upon which social progress depends. 


\section{Introduction}

Our concern in this chapter is democracy and the rule of law as conditions for social progress. Democracy is at its most basic, rule by the people This encompasses universal suffrage, free competitive elections, alternation in government and the absence of obstacles to participation in public life. Conceptions of democracy, however, have beenl extended to other sites, including the workplace and the community, and even theinternational order. The idea of democracy has been expanded beyond representative democracy and passive participation through elections, towards new forms of participative democracy. Democracy requires an institutional framework for its own protection to secure civil equality, without which it would be meaningless in practice. It has to protect against arbitrary government and the tyranny of majorities; to protect minority rights; to sustain opposition; to provide predictability and security; and to safeguard against corruption. This is where the rule of law comes in. This requires an impartial legal system, free from political coercion, and the equality of all citizens before it. In the past some conceptions of the rule of law were quite conservative, focused on defending existing privileges and property rights against the spread of democracy and demands for equality. The political left in some countries (such as the United Kingdom) were wary of charters of rights and legal limitations on the scope of government, fearing the rule of lawyers and of private interests. This opposition has largely disappeared. Yet in our day, there remains the danger that the law will be captured by private power holders.

During the second half of the twentieth century, there was a widely-held belief that democracy and equality before the law were a part of a broader process of modernization that carried the promise of global progress across a set of complementary 
spheres. Continuous economic growth under the impetus of technology would eradicate poverty and raise living standards. Social inequality would be reduced, bringing equality of opportunity and greater substantive equality. Rising living standards and greater equality were seen as conducive to the extension and deepening of democracy, allowing citizens to participate fully. Civil rights would extend to embrace the entire population on a equal basis. The nation-state provided both the demos and the institutional frame for democracy, and the model was adopted widely by peoples liberated from colonial domination. These elements would reinforce each other as prosperity would enhance democracy and secure political stability. Possible excesses of democracy, such as oppression of minorities and abuse of power were limited by its combination with liberalism in liberal democracy and by the rule of law itself. Political parties mobilized electors to participate, while providing programmatic policy alternatives. While different models of economic management competed during the first half of the twentieth century, a form of liberal regulated capitalism seemed finally to predominate, generating steady growth while curbing excesses of economic power. Remaining issues concerned the exact balance between the market and state, dividing pure market liberalism from social democracy. States possessed sufficient policy, regulatory and fiscal capacity to translate citizens' aspirations into substantive outcomes.

Our paradox arises from the circumstance that many of these promises have been met but they have been undermined by their own internal conflicts or by other social and economic trends. There were successive waves of democratization during the twentieth century, affecting most parts of the world. Legal orders have been strengthened and separated from politics in many states. Formally equal civil rights were extended without regard to class, ethnicity or gender. National welfare bargains within states secured a strengthening of social benefits and the extension of education, health and social benefits 
to larger sections of the population. Although these took place to very different extents depending on the country and region, there was hope for general progress.

In the early twenty-first century, we see less room for optimism. The formal apparatus of democracy and rule of law is intact across much of the world, but the conditions for their substantive exercise are weakening.

Formal political equality is undermined by the massive increases in social and economic inequality across much of the democratic world, which limits the ability of all to participate on equal terms. In the late twentieth century, there was a lot of talk about 'globalization' seen as an ineluctable process curtailing the autonomy of the nation-state. It is now apparent that globalization is a stretched concept, which means many different things. Rather than an ineluctable force, it is often the work of nation states themselves as they seek new scales of action to regain control of social and economic change. We define globalization as a new division of labour at the world level, eroding national markets and national systems of regulation. Its agents are states, corporations seeking new sites of production and markets, and international institutions. What is interesting for our purposes is not the broad concept but the form that globalization takes.

In its early twentieth century form, it has opened up a new class division, in some cases obliterating older cleavages including those from the industrial revolution. In a familiar form, it may pitch multinational corporations against nation states as the former engage in regulatory arbitrage and demand packages of taxes and services in exchange for investment. It reach is often even deeper, as it often pitches individuals with high levels of education, mobile skills and international connections, against those who lack these.

Within states, formal democracy is undermined by the ways in which economic power can be transformed into political power. This takes numerous forms, including the 
purchase of political machinery required in modern elections; the privileged power of large business in lobbying government, given their ability to relocate beyond the nationstate; and outright corruption.

Law similarly is formally open to all, but has become expensive, giving advantages to the rich and to corporations, which can claim some of the rights of persons. International trade deals can give corporations a privileged status against democratic governments, protected by a private form of arbitration outside the regular courts. Equal civil rights may be protected formally but social and economic rights may not. There is still corruption in many legal systems.

Political parties, which used to be a means for broadening political recruitment and transmitting voter preferences into government, have become detached from society while at the same time monopolizing state power. The old parties have become selfperpetuating, sustaining a closed elite of professional politicians.

This has opened the way for the rise of new political movements offering simplistic solutions to the problems of rising inequality and global change, often appealing both to the beneficiaries and losers from change. Populism is a broad term, used differently in different historical and political context but our concern here is with the rise of nationalist populism on the political right. We define national populisms by a number of key features (Werner Muller, 2016): that the 'people' has a single will and interest; that it is being frustrated by special interests and 'elites'; that opposition is unpatriotic and therefore illegitimate; that the national will is to be interpreted by a supreme leader. This is the basis for Viktor Orbán's call illiberal democracy. Other national populists include Trump, Duterte, Modi and Le Pen. In the United Kingdom, a 52 per cent vote in the Brexit referendum is taken as a a wide-ranging mandate for a specific manner of withdrawing from the European Union, with as little parliamentary 
intervention as possible; judges ruling that parliament must be involved re lampooned by the tabloid press as 'enemies of the people'.

Minorities and migrants are made scapegoats for the consequences of social and economic inequality. Populist nationalism can serve to induce working class electors to vote against their own economic interests, in the name of the national interest and against foreigners and elites. Not the least of ironies is that many of the politicians railing against the domination of 'elites' are themselves insiders of the old ruling circles and moneyed classes.

All this is facilitated by the decline of the old print and broadcast media and the concentration of media ownership in the hands of wealthy individuals and organizations, often beholden to private or state-controlled economic or ideological interests. In many cases, truth itself has become a commodity, to be purchased or constructed at will. Social media are sometimes seen as emancipating, allowing citizens to communicate freely but they are also unencumbered by regulation of standards. The phrase 'post-truth' politics has come into fashion, referring to the disappearance of shared empirical or epistemic knowledge upon which rival policy proposals can be debated. Donald Trump's spokeswoman can, without irony, talk of 'alternative facts', while the blatant untruth that the UK pays $£ 350$ million a week to the EU, which could be diverted to the National Health Service after Brexit was displayed on the side of a bus.

The nation-state, traditionally the main object of political competition, is less able to manage the process of social and economic change, so that democracy is detached from substantive policy capacity; hence governments of different political hues end up with similar policy outcomes. Faced with intractable social and economic challenges, states have sought various forms of automatic pilot that would guarantee success while relieving pressures on themselves. Hence, for example, the fashion for monetary policy 
as the master instrument of macro-economic stability, to be assured by giving central banks operational independence. Direct state intervention in many fields has been replaced by privatization, combined with regulatory agencies to ensure competition and public goals. Yet the regulatory state has itself become a massive reservoir of power, not always subject to democratic control and operating according to its own norms. This represents less of a retreat of the state than a reconfiguration in new forms.

At the same time as the state loses its capacity to produce social and economic change, its repressive capacity is enhanced in the face of real or constructed threats of disorder and terrorism. As the political agenda shifts from social progress to security, democracy itself produces a restriction of civil liberties.

The rule of law is also vulnerable to internal interests. Like political parties, the judiciary itself may become a class with its own vested interests, providing an obstacle to democratic change.

We also emphasize the role of ideas and shifting dominance ideologies. Over the last quarter of the twentieth century, monetarism displaced Keynesianism as the dominant economic paradigm. The failures of the new model in the financial crash of 2008 only briefly dented confidence it. Democratic politicians failed to provide a convincing counter-narrative to underpin alternative strategies.

The idea of liberalism was also transformed. Liberalism as a political doctrine emphasises individual freedom and a secure public domain for the expression of ideas. Economic liberalism is based on free markets, competition and a limited role for the state in economic management, beyond ensuring the conditions for competition. The two have often been associated, although frequently in tension. Neo-liberalism is a modern concept, often used loosely, stretched and loaded with a strong normative charge. We define neoliberalism as a political doctrine that asserts the superiority of the free markets of 
neoclassical economic theory over most other forms of decision-making, especially over the actions of government. For pure neoliberals, this implies a belief in perfect competition, but more influential in practice are those who privilege the role of corporations and their freedom, which often compromises free markets. There is therefore tension and ambiguity at the heart of the neoliberal project.

When neo-liberalism came back into fashion in the late twentieth century, the emphasis had shifted to the second meaning, based on the needs of corporations. Starting in universities and think tanks, neoliberalism, as an ideology privileging free market over social protection gained hegemonic status in the face of states' inability to handle the challenge of economic change after the 1970s. This has entailed dismantling a citizenship regime of civic, political and social rights. Privatization, deregulation and liberalization have reduced public resources to mitigate social inequalities. The very notion of democratic capitalism, implying that democracy favours the development of capitalism, was challenged (Streeck 2015). Neo-liberalism thus undermines the historic principles of liberalism itself, a paradox that was well known to Adam Smith. The paradoxes we are going to discuss in this chapter are embedded in the crisis and 'strange non-death' of neoliberalism (Crouch 2013).

Developments in the first part of the twenty-first century thus represent not a mere swing of the pendulum from left to right but a fundamental challenge to the liberal democratic order toward which the world seemed evolving during the latter part of the twentieth century. The very conception of democracy as liberal democracy (based on delegation and majority voting) is under stress as neoliberalism has attacked those very intermediary institutions (parties, unions, voluntary associations) that had been at the basis of the development of the welfare state and democratic capitalism. 
Yet we do not want to be totally despondent. There have been notable reactions to neo-liberalism. Some may have represented what Karl Polany (1957) called 'countermovements' for social protection, conceived of as spontaneous and backward-looking. Other societal responses seek to promote alternative visions of democracy, stressing participation over delegation and deliberation over majoritarian decision-making.

While electoral accountability is jeopardized by a growing investment of economic resources in the political sphere, other visions and practices of 'counter-democracy' develop. While elections are a central feature of democracy, stressing only elections can distract attention from the need for critical citizens who can render governors accountable. Representative democracy thus needs to be matched by participatory practices, continually linking policy to citizen concerns.

Another requirement is an informed public sphere, with some shared standards of truth. This is not to say that objective facts will produce political consensus but that arguments can at least be tested. This in turn can produce communication, deliberation, the exchange of reasons, the construction of shared definitions of the public good, as fundamental for the making and legitimation of public decisions. By relating with each other - recognizing the others and being recognised by them- citizens have the chance to understand the reasons of the others, assessing them against emerging standards of fairness. Communication not only allows for the development of better solutions, by allowing for carriers of different knowledge and expertise to interact, but it can also change the perception of one's own preferences, making participants less concerned with individual, material interests and more with collect goods.

There is also a need to question the nation-state as the primary site of democracy and the rule of law. Talk of 'globalization' and the end of the nation-state around the end of the Cold War was overblown and the nation-state remains a formidable centre of 
power as well as object of political attachment. Yet the challenges of inequality and democracy arise at multiple levels, below, above and across states as well as within them. The nation has been a force for progress and solidarity but also for exclusion and aggression. Rather than illusory slogans about 'taking back control' (as in the Brexit referendum) or appeals to common enemies (as in national populism), it is important to democratize the multiple scales at which policies are made. This requires new forms of institutional design.

There are inescapable dilemmas in all this. The rule of law cannot be the mere plaything of politics, as with a Silvio Berlusconi. Nor, however, can law be separate from the rest of the public domain. Governments should be subject to the rule of law but should judges not be made into legislators. The market has been a powerful generator of wealth but, left to its own devices, can undermine democracy itself. In the 1930s, democracy and the rule of law collapsed widely because of their enemies offering a radical alternative. In the twenty-first century they risk being undermined by forces purporting to act in their own name and by their own excesses and contradictions.

In the following sections, we observe specific challenges to the liberal model of democracy, but also opportunities for the development of different models of democracy, more participatory and deliberative.

We observe how neoliberalism allowed the owners of economic resources to influence political decisions, and the effect this had in spreading of corruption and reducing citizens' rights. The very conception of the rule of law is challenged by unequal access to the judicial system. Public life is rescaling at multiple territorial levels, posing questions about equality and democracy but also opening up new forms of engagement. Democratic paradoxes are also visible in the development of some of the principal democratic actors, from parties to social movements, which see their organizational structures and modes of 
functions transformed. The very right of dissent is challenged, as neoliberalism spreads insecurity, but at the same time different paths of political participation emerge.

\section{Capitalism, inequality and democracy ${ }^{3}$}

In the days of the Cold War it was usually taken for granted that capitalism and democracy were natural partners. The situation has now changed. Some serious writers on contemporary politics have even begun to doubt whether democracy and capitalism are mutually compatible (Kocka 2014, Merkel 2014, Streeck 2015). A major source of disquiet is the implications for democracy of rising inequality. This disquiet comprises the following elements:

1. Unless significant regulatory measures are taken, there are no means within a capitalist economy to prevent the conversion of economic into political resources, and the dominant capitalist ideology, neoliberalism, is hostile to such regulation;

2. In an open political system, concentrations of wealth have particular advantages in exercising influence because they are spared the problems of collective action that limit the activities of other groups;

3. This influence is used to extract political favours in the interests of the wealthy, further increasing inequality and interfering with the market order, producing a spiral of growing inequality and economic distortion.

We shall examine each of these contentions in turn.

\subsection{The mutual convertibility of economic and political resources}

\footnotetext{
${ }^{3}$ An extended version of some of the arguments in this paper will be found in Crouch, C. 'The Paradoxes of Privatisation and Public Service Outsourcing', in Jacobs, M. and Mazzucato, M. (eds), Rethinking Capitalism: Economics and Policy for Sustainable and Inclusive Growth. Oxford: Wiley Blackwell, 2016, 156-171.
} 
In a perfectly competitive market economic resources should not be converted into power, and therefore can have no political implications; spending money on politics would be a business cost, and a firm engaging in such activity would have to raise prices and lose out to firms that did not so engage. All firms in a sector might avoid this problem by combining to lobby for their political interests, but coordination among a large number of firms runs into the collective action problem (see below), defection from the coordinated action bringing cost advantages to the defectors. However, the situation changes when many markets are only imperfectly competitive. Here economists divide into those who accept no other solution than trying to establish perfect competition and those (associated with the anti-antitrust movement, mainly in the USA) who argue that advantages flow from imperfect competition (Bork 1993, Posner 2001). These are not concerned with the political implications but to claim that returns to scale are more or less infinite, and that therefore there are no reasons to seek to establish perfect markets. For them, unlike pure neoclassical theorists and Ordoliberalen, a competitive order exists where some firms win the competition and thereafter dominate, not one where competition is permanent.

We can here draw a distinction between two types of neoliberalism, which will be important to the general argument: market neoliberals, whose main concern is that markets function; and corporate neoliberals, who defend the role of large, oligopolistic corporations. These latter rarely confront the political implications of the build-up of large profits that their approach implies, but if they do they argue that if governments abstained from interference in the economy, there would be nothing to lobby about and firms would have no incentive to be politically active (Bork 1993). However, as was demonstrated in the financial crisis, certain sectors can be both dominated by a small number of firms and so strategically important for a national (or the global) economy, that the collapse of a small number could provoke a massive shock. This is the 'too big to fail' argument. It is clearly the case for banking; it is probably 
also true for energy, defence, and for certain privatized public services. Firms in these sectors have a clear incentive to become politicized, as they have much to gain from government. The uneven distribution of political influence that this implies, even among businesses in different sectors, let alone in comparison with the rest of the population, embodies part of the asymmetry and inequality that make business lobbying questionable on both marketeconomic and democratic grounds.

The barrier that neoclassical theory would erect between polity and economy is a semi-permeable membrane; restraints are imposed on the state's ability to intervene in the market, but not on corporations' intervention in the polity. Indeed, in the USA such activity has been explicitly accepted by the Supreme Court. In 2010 it rejected a ruling by the Federal Election Commission that there were limits to the sums of money that organizations could spend on election campaigns, on the grounds that the US Constitution should be seen as having granted the same rights to organizations as to individuals, though it maintained the existing limits on such donations to individual candidates (US Supreme Court 2010). Four years later, however, it also removed the ban on the second kind of donation (US Supreme Court 2014). It is primarily large corporations that are able to make donations of this kind.

\subsection{Wealth and the problem of collective action}

There are two aspects to liberal democracy: the formal processes of elections, where rules to ensure strict equality among all citizens are accepted as paramount; and the informal debating, lobbying, and other activities that link the world of government to society between elections. Here there are no guarantees of equality. The theory to support the latter was developed, largely by US political theorists, in the 1950s and 1960s under the general banner of pluralism or polyarchy (Dahl 1971). This dealt with the risk of an undemocratic inequality of influence in the informal arena by positing that the need for relative equality would be met if there were 
large numbers of groups trying to influence government, using a diversity of non-overlapping types of resource, and usually being effective only within specific, limited areas of policy. In that way, no one interest would dominate. As in the free market, provided that there are many participants in the market/polity, all are price-takers and none can exercise significant influence by acting alone.

There remained the risk of a hyperactive polity, with governments vulnerable to lobbying at every moment. Pluralist theorists dealt with this by pointing out that in general people were not politically active; Robert Dahl (1961: 305) remarked that 'Politics is a sideshow in the great circus of life'. Such observations were placed on a stronger theoretical basis when Mancur Olson (1965) developed his theory of collective action. This demonstrated the difficulties of participation in collective action. First, if a movement were big enough to be likely to succeed, it would do so without the participation of any one individual, whose contribution would be infinitesimal to the movement though costly to that individual; therefore individuals had only a very low incentive to participate. Second, if the movement were aimed at a collective good rather than a membership good, individuals would benefit from its success even if they did not participate; again the incentive to take part was very low.

The pluralist account of western democracy was being developed during the historical period when inequality was lower than at any time in the recorded past (OECD 2011; Piketty 2013). Now that inequality is increasing again, the account is becoming unrealistic. Olson envisaged a world in which people had no means of co-ordinating their actions except through voluntary individual action. This does not apply to persons and corporations possessing considerable wealth. They do not need members; if they need human resources they employ people. The very wealthy are therefore an exception to the collective action problem, provided that they have enough incentive to bother to take action. They have this where governments might be in a position either to favour or frustrate their private interests. The 
assumption of pluralist theory that in a market economy firms are just some among many interests then falls - a circumstance that was indeed perceived and warned against by two of the leading US pluralist theorists right at the start of the current period of growing inequality one of them being Robert Dahl himself (Dahl 1982; Lindblom 1977).

\subsection{The spiral of inequality and corporate political power}

The ways in which growing inequality, corporate power and politics interact take many forms. The OECD's (2011: $122 \mathrm{ff}$ ) analysis of growing inequality identified several causes, among them sectoral change; the growing finance and related business services sector being a particular source of growing inequality. It also identified 'institutional' and 'policy' factors. The latter can be seen particularly clearly in taxation, changes in which have been responsible for producing some of the growing inequality (OECD 2011). In the face of growing pre-tax income inequality a democratically responsive fiscal regime would be expected to improve the progressivity of taxation, while one caught up in mutually reinforcing inequalities of economic and political power would make regressive changes. The fiscal changes of the neoliberal period have been consistent with the latter hypothesis.

An institutional change that the OECD identified was the decline of coordinated collective wage bargaining. There is a close though not perfect relationship between the extent of coordinated collective bargaining and trade union power. There is also a correlation between trade union power and post-tax and -transfer inequality: the greater the degree of union power, the greater the extent of redistribution produced by the fiscal system (Crouch 2016). Interestingly, union strength correlates far more strongly with post-tax than with pretax inequality, suggesting a political rather than an economic effect of union challenge. Almost everywhere coordinated bargaining, union strength and fiscal redistribution have been 
in decline, reducing the role of what had been a major form of countervailing power against capital in more pluralist times.

\subsubsection{Business lobbying}

The above discussion has concentrated on the challenge to the mutual compatibility of capitalism and democracy presented by growing inequality. But this is not the only reason why corporate interests are exercising a political influence that is seriously unbalancing a democratic pluralism. Since the collapse of Keynesian demand management, according to which governments undertook to sustain the level of employment, the dependence of the population on a high level of employment has become an important argument at the disposal of neoliberals. For market neoliberals this means the contention that wages and non-wage labour costs must be allowed to fall until all idle labour can find employment. This is, for example, a major part of the policy package imposed on Greece in the wake of the Euro crisis. For corporate neoliberals it means arguing that if governments want to reduce unemployment, they must listen to what corporations say they want. This can mean labour-market measures less harsh than the market neoliberal recipe, but it also involves granting privileged political access for the corporate leaders, who of course interpret a general interest in the light of their own private ones.

For market neoliberals, efficiency is achieved when markets clear. Aspects of life that, looked at more broadly than through the framework of economic theory, might be seen as important but which are not or by their nature cannot be represented within market exchanges are either insufficiently important to merit consideration, or are just unfortunate not to be able to be taken into account. Examples would be a perceived need to safeguard poor people's basic standard of living when they cannot find work that would provide such a standard, or most types of environmental damage. For the pure theory, attempts to take such issues into 
consideration through regulation necessarily reduce efficiency because this is per definitionem measured only through the market.

\subsection{Conclusion: growing tension between capitalism and democracy}

In the light of all the above, we are forced to ask whether capitalism and democracy are today as mutually dependent as they seemed to be during the Cold War. Is 'republican democracy' still 'capitalism's best possible shell', as Lenin claimed? Capitalists are believed to have a preference for democracy, because they tend not to like dictatorships, which use a lot of state power, can be arbitrary and change rules without due process. Modern democracy more or less guarantees the rule of law, and clear procedures for changing law and lobbying around proposed changes. On the other hand, democracy can produce a mass of regulations to protect non-market, non-corporate interests. Capitalists' preferred regime is post-democracy, where all the forms of democracy continue, including importantly the rule of law, but where the electorate has become passive, responding to parties' carefully managed election campaigns, but not engaging in disturbing activism, and not generating a civil society vibrant enough to produce awkward counter-lobbies that try to rival the quiet work of business interests in the corridors of government (Crouch 2004).

The major phenomena that to date have disturbed this system are the xenophobic movements that played powerful roles in the votes of the British and US electorates respectively to leave the European Union make Donald Trump president, and in becoming serious contenders for power in France, the Nordic countries, Austria and the Netherlands. While these movements include 'liberal elites' in their critique of contemporary society, they are ambiguous about whether they include business elites in that category; Donald Trump is himself at the heart of the US business elite. In any case they concentrate their serious attacks 
on ethnic minorities and immigrants, as well as fear of Islamic terrorism, and it seems to be for this reason that they attract most support.

It is unlikely that these movements constitute a serious democratic challenge to capitalist dominance over politics. If anything, their use of powerful emotional xenophobic rhetoric against formal political institutions raises doubts about their commitment to the procedural rules and open debate that underpin democratic institutions. This became clear in the UK following the EU referendum, when newspapers that had campaigned for the vote to leave the EU attacked the law courts for ruling that the national parliament should be involved in the Brexit process.

In any case, post-democratic capitalism does not require a formal renunciation of democracy any more than corporate neoliberalism requires a renunciation of the market; indeed, democracy and the market continue to be used as the primary legitimation of the evolving political system of dominant corporate power, because this latter lacks any legitimation of its own. Elements for such a legitimation are there, but they are used in a supplementary way (Crouch 2015). For example, anti-antitrust theory provided a justification for protecting market-dominating corporations from market-making competition law. New public management theory legitimates the abolition of boundaries between public officials and corporate personnel, seen so important to an earlier age of liberal economy. Corporate social responsibility both gives business leaders a social legitimation going beyond their role as profit-maximizers and suggests that public policy is not needed to tackle many market failures. In the absence of Keynesian demand management, the widespread desire for a high level of employment gives priority to the policy preferences of business interests.

We have not yet arrived at a situation where corporate dominance of our politics is complete, otherwise all consumer protection and labour laws would have already been abolished; governments would not be continuing to develop regulations to try to reduce 
smoking. But this is the direction of travel, strengthened by continuing growth in inequality and the mutual reinforcement of political and economic power. Democracy in some form probably continues to be the best possible shell for capitalism; but vice versa may no longer apply.

\section{Corruption, neoliberalism and democracy}

In recent decades a chain of scandals has fueled a growing popular awareness of corruption as a factor which may negatively affect political and economic decision-making, distorting public policy through growing ineffectiveness and inequality, not only in less developed and authoritarian regimes, but also in advanced, capitalist liberal-democracies. The observable nexus between established democracy and transparency (Pellegata 2012)does not protect against reversals: Australia, Iceland, Spain, Argentina, Brazil, Cyprus, Hungary, for instance, have experienced since 2012 a sharp increase in the level of perceived corruption according to the Corruption Perception Index of the NGO Transparency International, the most widely used proxy which estimates its diffusion through subjective experts' assessments.

Citizens' beliefs in the same years follow a trend to harsher feelings about corruption, driven by at least two factors. First ishe repeated uncovering of grand corruption networks in some democratic countries from the 1990s Italian 'clean hands' investigation to the recent Petrobras and Lava Jato cases in Brazil. Theseoften also involve the private sector, as in the stream of banking and financial scandals (from the United States to Germany). Second isthe extensive use in the political debate of a 'corruption issue' against traditional élites, often framed within populist appeals. The perception of rampant corruption in the political, economic and financial arenas has been a leading factor in a growing dissatisfaction with elites, expressed in radical protest against the wealthiest people who exercise an opaque political influence, converting their disproportionate share of financial and material capital 
into hidden relationships with public actors. According to the 2013 Global Corruption Barometer (GCB) international survey, on average in the 54 democratic countries considered 53 per cent of respondents believed corruption had increased in the previous years; 33 per cent thought it had stayed the same and15 per cent thought it had reduced. The 2016 Regional GCB provides an similarpicture of distrust in European Union countries, where 65 per cent of citizens think that wealthy individuals often use their influence on government for their own interests and support stricter rules to prevent this. Liberal democracies where bribery is perceived as significant suffer a mounting de-legitimization of elected representatives and political institutions. Responses have included anti-establishment movements; an 'exit' strategy of abstention or disengagement from political activity; and the rise of populist political leaders waving the issue of corruption to challenge 'old' and 'crooked' political representatives, occasionally threatening the stability of democratic institutions. Large-scale corruption in the public sector is at the same time a signal of the failure of the institutional and societal mechanisms of control over the integrity and effectiveness in public agents' delegation of power, and a challenge to the basic principles of democratic government, such as equality, responsiveness, accountability, transparency. Corruption within democracy is necessarily also corruption of a democracy.

\subsection{Beyond the neoliberal paradigm of corruption}

In the economic literature, corruption is a rational response to contextual opportunities, generated by distortions of the relationship between a principal (the state, in case of the public sphere) and agents, often induced by the involvement of a third-actor, the corruptor (Banfield 1978, della Porta and Vannucci 1999). This theoretical framework underlines how institutional variables such as monopoly power, opacity and discretion in decision-making, create opportunities and incentives for individuals to enter into corrupt exchanges (Klitgaard 1988). Neoliberal doctrine has provided the basic theoretical toolkit underlying anticorruption 
measures and reforms sponsored in the last decades by inter-governmental and international organizations, particularly OECD, World Bank, United Nations, IMF. Bribery is seen as the predictable byproduct of the undue intrusion of the state into the activity of competitive markets, both through public services (which should be replaced by a market for equivalent private commodities) and through regulation (whose burden is unnecessary given economic agents' self-restraining and free contractual agreements). Privatization, liberalization, cuts in public spending, and deregulation are the recommended policy for an effective and longlasting reduction of corruption. The adoption of an anticorruption regulatory framework consistent with the limitation of state interference with markets has often been imposed as a prerequisite for the distribution of economic aids and investments.

In its practical application the neoliberal paradigm has shown severe drawbacks. The retreat of the state underlying neoliberal policies may itself be corruption-enhancing . This isexemplified by the bribery aimed at distorting or manipulating privatization processes of public enterprises and assets (Rose-Ackerman 1999), as well as by the strategic interest of large corporations, merchant banks and other oligopolistic actors in obtaining a more favorable and looser regulatory environment of their high-profit activities, while discharging social, environmental as well as financial costs onto the public. The externalization of public services or the recourse to contractual provisions allowing private corporations to play a crucial role even in the definition and satisfaction of public needs has increased managerial discretion and weakened public accountability. Coherently with the New Public Management approach, shifting between public and private roles has been encouraged, breaking down barriers that prevented revolving doors between government departments and firms. As a consequence, corrupting penetration of private businesses' interests into policy-making has been often observed, rather than the presumed adoption of efficiency-based organizational models in the public sector. In an extreme manifestation of this -Berlusconi in Italy and 
Trump in the USA - businessmen who were previously used to influence (and bribe) public decision-makers enter into politics in order to get protection, invoking the rhetoric of entrepreneurial success as a rewarding strategy in their direct appeal to the 'people'. Moreover, any reduction of the state's role in the economy necessarily generates a large set of un-regulated, opaque, unaccountable interactions between public and private agents, lobbies, large corporations and other organized economic interests.

The failure of anticorruption policies inspired by the application of the neoliberal paradigm has been widely observed and criticized (Ivanov 2007). Moreover, all international rankings, like Transparency International's Corruption perception index, or World Bank's Corruption control indicators, consistently show the (apparently) paradoxical outcome: the world's maximum degree of integrity in the public sector can be observed in Scandinavian countries where public regulation and state intervention in the economy and the society are highest. This calls for additional explanations and alternative policy measures.

\subsection{Corruption and the blurred boundaries between political and economic power}

While the complementarity between capitalism and democracy was usually taken for granted, corruption is a symptom of subterranean frictions between the two. Liberal-democratic regimes establish, through institutional and informal constraints, a boundary between internal power, deriving from the occupation of roles of public authority, and economic power, deriving from the market process. In a wider perspective we can look at corruption as a practice - more or less 'institutionalized' in itself - that covertly and therefore unaccountably converts economic into political resources and vice versa, blurring the frontier separating the public and the private sphere. Corrupt activities are usually but not necessarily illegal, since this condition depends on the capability of the legal order to identify and sanction them. Additionally, the very definition and effective enforcement of corruption in legal terms may 
be influenced by corrupt politicians and judges, becoming the object of a symbolic contention on the acceptable boundaries between state, markets and society; individual and collective interests and rights; the proper extent and limits of market, bureaucratic and patrimonial allocation of resources; and public and private roles (Johnston 1996).

Corruption implies the application of the price system to legal procedures and rights. Therefore it is not only contrary to democratic values, it also obstructs the efficient functioning of the market itself (Arrow 1972). The development of inclusive, as opposed to rent-seeking and extractive, economic and political institutions, provides more effective and credible commitments of rulers and economic actors to a limitation of excessive privatization and conversions of the public goods into privately appropriable rents (Acemoglu and Robinson 2012). When corruption happens in a liberal-democratic regime, a market for the exercise of public authority replaces official procedures which, under the rule of law, should provide impartial and universalistic criteria in the allocation of goods and services. Privatization can hardly be a remedy against bribery, since behind any form of corruption lies precisely a hidden and unaccountable privatization of resources in which secret networks of public and private agents exchange rents. This invisible 'privatization' process implicit in bribery explains the strong relationship between economic inequality and corruption across both developed and developing countries (Gupta, Davoodi, Alonso-Terme 1998). The inequality trap is the outcome of a positive-feedback mechanism fueled by the impact of perceptions of pervasive corruption on both mistrust in the quality of government's services and unequal allocation of resources, which in turn encourages both tax evasion and the search for selective inclusion in the cliques of privileged ones, through hidden influence and corruption, therefore further increasing unfairness (Uslaner 2013). Successful attempts of corrupt agents to minimize public scrutiny, visibility and risk, through the strategic use of their official roles, further undermines vertical and horizontal accountability. The potential for 
corruption generates economies of scale in a wider set of other illicit activities, since corrupt exchanges with regulators, public supervisors and enforcers to avoid control and sanctions are intertwined with other ills including fiscal evasion, financial frauds, bankruptcies and irregular industrial waste dumping (della Porta and Vannucci 2012).

\subsection{Corruption as an enduring challenge to democratic principles and practices}

After the ephemeral triumph celebrated with the collapse of Communism in Eastern Europe, the democratic model has been shaken in the last decades by a series of tensions. Evidence and perceptions of widespread corruption are among the most acute symptoms of democracy's unresolved challenges, and a hidden factor that tends to exacerbate them. They contribute to the spiraling costs of political activity and the decline of political participation and traditional parties, linked to the impotence of political leadership, in the face of recurrent economic crisis and deterioration in public budgets, to resist to the capturing influence of strongest economic and financial interests. But they also facilitated the rise of populist or extremist parties and leaders, openly questioning liberal-democratic values and the sustainability of the welfare state..

Far beyond the inflated cost of public works and services, inefficient contractor selection and the waste of resources due to rent-seeking, other long-term negative consequences of corruption affect the quality of democratic processes (Johnston 1986). Pervasive corruption alters the relative allocation of public spending, penalizing sectors where rents are more difficult to extract, such as education, social security and welfare. A relatively higher portion of public budget is allocated to huge infrastructural projects, defence and other sectors where monopolistic or oligopolistic corporations control the public markets (Mauro 1998). In the longer term, countries with a lower public investment in education will suffer a diminished level of accountability, due to a weakened capability of citizens to effectively 
control their decision-makers, mobilize in collective actions, recognise and sanction malfeasance (Arnone and Boldrini 2014).

Even the way out of rampant corruption offered by populist right-wing leaders is inherently coherent with the neoliberal perspective they criticize. The basic solution envisioned against the multiplication of abuses of entrusted power is a drastic simplification. Bypassing the traditional multiple subjects of political delegation of power in representative democracy, they propose the strengthening of a unique, direct linkage between the masses and Trump-like charismatic leaders, whose reliability in anticorruption should be assessed by their capacity to 'speak straight' and plain, by their success as entrepreneurs and non-involvement in 'old' politics, aND by their wealth - which is supposed to make them immune to temptation. But the 'unconditional trust' they ask for from the people is the most vulnerable to arbitrary abuses of power and unaccountability, especially when - as the media tycoon and former Italian Prime Minister Berlusconi clearly shows - it is instrumentally invoked to justify a weakening of the rule of law, gaining impunity from judicial inquiries through special laws.

A basis for alternative, more effective anticorruption reforms lies instead in a simultaneous promotion of bottom-up initiatives, empowering societal actors, allowing them to influence those political entrepreneurs with the authority to change the formal 'rules of the game'. The mobilization from below of civil society and local communities' participation in anti-corruption policies may set in motion a positive interplay between actors' interests in integrity and optimistic expectations that an exit from systemic corruption can be found. In recent years, social movements denouncing kleptocratic practices have developed a radically different explanatory framework, where the fight against corruption is a basic constituent of a wider effort of citizens to oppose deterioration in the quality of democracy. Experiences that increase the citizens' opportunities to participate in public policies increase information 
available to the public, spreading a broad awareness and knowledge that in the 'technocratic' conception of politics are kept hidden (della Porta, Font, and Sintomer 2014). The fight against corruption, re-framed as a public good, requires an effective defence of citizens' rights against the arbitrary power of the political bosses to whom particularistic demands are addressed. Among the crucial factors that increase the possibility of success are better access for individual and collective actors to an independent judiciary, in order to denounce discrimination and privileges, especially when such practices strengthens social awareness (Vauchez in this chapter).

In recent mobilizations from below, corruption is defined as a problem of social justice, rather than a mere obstacle to good government, which could be effectively curbed widening the forms of political involvement through participative democracy (della Porta in this chapter). Decentralized knowledge and citizen awareness are often as insightful as experts' understanding. Public responsiveness spreads thanks to a wide stigmatization of political malfeasance. Spanish indignados ironically set the 'state of malestar' against the 'state of bienestar' (the state of malfeasance against the welfare state). In recent years, information about and censure of corruption circulated thanks to the support of NGOs, movements, groups and activists, from Wikileaks to individual bloggers, to networks and eplatforms. This process encouraged the development of both vertical and horizontal accountability mechanisms, oriented not to punishment and enforcement, but also to raising public awareness. The fight against systemic corruption, a factor of degeneration and injustice affecting many representative democracies, cannot be a single-issue policy, nor delegated only to experts' advice to policy-makers, but rather must be linked to a wider rethinking of politics and participation (della Porta 2013). 


\section{The territorial dimension}

\subsection{The bounded nation-state}

For a long time, social and political theory presented modernization as a process of territorial integration and functional differentiation (Durkheim, 1964). This stemmed from functional factors, including the expansion of markets, the division of labour and the diffusion of language and cultural norms (Deutsch, 1972). States promoted cultural homogenization and uniform administration and services. State boundaries turned social and economic demands, and their political articulation, inwards Rokkan (1999). Capitalism developed within a national framework in symbiosis with the state; labour organization followed. Economic and social systems were thus 'caged by the nation-state (Mann, 1993).

There was a strong normative component to these theories as the nation state was seen as the necessary framework for social progress. Democracy, from the nineteenth century, was usually defined in a national mode, the nation providing the demos. Civil and human rights were based on unitary and national citizenship.

Following the Second World War, Keynesian macro-economic policies were predicated on integrated national economies. Spatial development policies aimed at further integration by bringing lagging regions into national markets. Post-colonial states also pursued national economic integration sometimes through protectionism.

For the welfare state the unitary nation-state provided affective solidarity and the necessary scale for redistribution. Welfare settlements rested on a positive-sum social compromise between capital and labour, both confined to national boundaries so unable to 'exit' (Bartolini, 2005).

The European state model became the precedent for state-building elsewhere in the world, where new states were aware of their own precariousness Again there was a strong normative bias, with diversity, pluralism and dispersed authority being associated with pre- 
modern political tradition and unity and integration with modernization, democracy, equality and welfare.

There was a central paradox at the heart of this deterritorialization and integration perspective. Territory was disappearing within states while becoming the supreme factor in differentiating states, economies and social systems from each other. Solidarity, too, worked within states but not across them. The paradox became apparent with the rise of new forms of transnational economic, social and political order.

\subsection{Rescaling the State}

In the aftermath of the Cold War, there was a brief moment of triumphalism as some scholars celebrated the end both of history and of territory with the victory of American liberal capitalism and 'globalization'. Progress had reached its logical conclusion as particularism gave way to a universal normative order.

In fact, what ended was not territory but the nation-state's monopoly over the definition and management of it. Rather than de-territorialization there is a re-territorialization. This is 'spatial rescaling' by which functional systems, identities and institutions are migrating to new territorial levels, above, below and across the state system (Keating, 2013). This process may be progressive or regressive.

Economic processes are reconstituting at the global and transnational levels, with free trade, mobility of capital and the large corporation. At the same time, sub-state territories are sources of economic dynamism. The emerging global division of labour is by no means blind to territorial differentiation. Indeed, some of the industries that might appear to be prime candidates for deterritorialization, like financial services or software design, are the most concentrated spatially. 
One perspective sees places as subordinated to a global division of labour as capital seeks out locations for production, jumping national boundaries. The city-region concept (Sassen, 2000; Scott et al., 2001) presents urban locations tied together in global production chains, dislocated from their host states. Another perspective sees cities and regions as more than mere locations of productions but production systems, with their own internal logic Crouch et al., 2001).

In a further move, these systems are portrayed as being in competition with each other as Ricardian comparative advantage gives way to absolute advantage (Scott, 1998). This is a contentious point (Bristow, 2010). Many economists insist that only firms compete and that talking of regional competition reifies spatial entities. The idea of inter-regional competition is an interpretation promoted by certain actors for specific purposes. States and transnational agencies have taken it as a complement to models of endogenous development based on what regions can do for themselves, to supersede the old diversionary regional policies and permit a disengagement from spatial equity. All regions and cities are told to become more competitive although, logically this is impossible; territories can become more productive, but that is another matter. For local and regional leaders, it provides the opportunity to expand their support base by postulating a common territorial interest.

This new regionalist thesis has been taken up by the political right, the left and the centre. On the right, Ohamae (1995) argues that globalization means the end of the nationstate, to be replaced by regions, competing in a rigorous market order. Alesina and Spoloare (2003) derive the size of 'nations' (by which they mean states) by reference to external trading conditions. In eras of protectionism, there is a tendency to large states, to secure extensive home markets. In times of free trade, global markets are open, home markets are less important and small states are more viable. With a smaller population, they can achieve greater homogeneity of public policy preferences through ethnic homogeneity. The argument 
is neither theoretically coherent nor empirically sustainable (Keating, 2013) but provides the intellectual underpinnings for the political right to deploy policies based upon a mixture of neo-liberalism, neo-mercantilism and ethnic particularism.

The consequence might be a 'race to the bottom'. As localities compete for investment, they may cut taxes and social and environmental provision. Inter-regional solidarity will suffer as states reduce support for territorial cohesion.

Intra-regional solidary can also suffer as social and economic actors may engage in 'partial exit' from national social compromises (Bartolini, 2005). Mobile actors and businesses can physically relocate or play regions off against each other. Such an outcome may be attractive to the political right but seen as a threat by the left.

The race to the bottom is not inevitable nor free from contestation. Austerity, plant closures and service retrenchment are often felt first at the local level, generating territorialized responses. State spatial development strategies and the intrusion of global economic forces generate local conflicts over land use and displacement. Oppositional social movements often mobilize at a local level. Urban struggles often focus on land use, pitting private profit against public utility in specific places, and on access to, spatially-delivered public services. This has made the city and metropolitan area key sites for distributional conflicts and for a left-wing regionalism. Mobilization of indigenous peoples in the face of the intrusion of international capital and state development strategies will often take on a territorial form.

Contestation also comes from movements based on the revival of old, or creation of new, territorial identities and demands for political autonomy. In the 1970s there was a tendency to write this off as evidence of retarded modernity, a violation of the national integration teleology. A less prejudicial view is that political identities as continually in flux, with the nation-state providing one historically-specific fix. Some new nationalisms are linked to 
exclusion, xenophobia, welfare chauvinism and opposition to immigration, and associated with the political far right. Others are socially liberal and politically social democratic. Many have fastened onto the new regionalism in economics to make an argument for the economic viability of smaller places in the context of global change and support transnational integration as a way of constructing a broader external support system for small polities. In many cases, sub-state territories have emerged as spaces for resistance to welfare retrenchment. Where there is an existing affective solidarity based on a competing national identity, this may provide the basis for defence of welfare.

In the political centre there is a vision of the region as a space of consensual governance, where that term refers to cooperation on agreed policy goals. Rescaling has been accompanied by depoliticization of key policy tasks. A new managerialism has focused on 'delivery', without asking what is to be delivered. Depoliticization is matched with a change of scale, as with monetary policy in the Euro zone. At the regional level, development agencies have often been given a degree of operational independence and insulation from local distributive pressures. These forms are often legitimated (by states and international agencies) in the language of 'governance', given a positive normative spin as politics-free problem solving.

So rescaling is, in itself, neither progressive nor conservative but, rather, a field of contestation. Territory is not a mere topological concept but a sociological concept whose substantive content is filled in through political and social struggle. Decentralization may not produce a race to the bottom but a race to the top if the territory concerned is more solidaristic than the state level.

\subsection{Institutions}

States have responded in various ways to rescaling as representation, accountability and welfare as social and economic processes have escaped their purview. One strategy involves 
centralized or technocratic forms of territorial administration, matching the scale of policy systems. Another is decentralization to regional and local levels, while retaining strategic control at the centre. The old idea that there is an optimal level for each governmental competence has been revived in arguments about structural reform, both in domestic politics and in recommendations of global agencies for structural reform. Yet, the optimal level for any function will depend on what the objective is and cannot be deduced from abstract principles.

State territorial management strategies are challenged by bottom-up forces seeking the democratization of territorial governance by seeking responsible government, based upon representation and democracy. They challenge technocratic and economistic conceptions of territory by pressing social, environmental and distributional issues.

This has provoked a series of conflicts over institutions. The boundaries of territorial institutions can define the scope for distributive politics by including rich and poor, as well as the balance of political power. The internal constitution of territorial institutions may privilege central government, technocrats or elected bodies. Decentralization may expose vulnerable territories to the discipline of global competition or offload welfare responsibilities and expensive commitments. It may equally be a way to re-establish democratic input to, and control of, social and economic change.

Rescaling poses a challenge to a vision of the integrated nation-state as the inevitable outcome of modernization or as normatively desirable ideal. It reminds us that, historically, there have been other forms of political order and there is no teleological necessity for a particular spatial order (Sassen, 2008; Ferguson and Mansbach, 1996). The response need not therefore entail the recreation of the twentieth-century state form, which had its bad sides, including exclusion, aggression and domination. Inclusion and solidarity can no longer be 
entrusted to the centralized state alone, but must be built into systems of public policy making at all levels.

\section{The constitutional challenge of national pluralism}

As noted in the previous section, the central concept of political and constitutional modernity is the idea of the nation-state, which assumes the consolidation of modern states around the notion of a single cohering national identity. One of the most significant ways in which the pretensions of the nation-state to be the natural mode of modern political organization has been challenged is by the persistent autonomy claims made by sub-state or stateless nations within extant state polities. The condition of 'national pluralism', which denotes the existence of more than one group claiming a national identity within the historical and territorial space of a state, and the accompanying rights claims asserted by these groups as nations, raise fundamental questions for established conceptual categories of law and politics in relation to nationality and statehood.

\subsection{National pluralism: a global policy challenge?}

Identifying what is and what is not a multinational polity can be analytically very difficult, not least because sub-state groups themselves are often unclear about the type of constitutional claims they wish to assert. Sometimes the 'national' character of these claims is motivated primarily by strategic considerations in the face of unaccommodating host states. In others, such claims may be impossible to articulate due to the hostile and repressive political atmosphere created by the host state. In yet others, groups may make 'nationalist' claims without necessarily demanding recognition as distinct nations. Most commonly and with only a handful of unusual exceptions across the world, however, nation-states do not recognise multiple nationality claims within their territorial boundaries at a constitutional level, even 
where some states may adopt sub-constitutional policies to address the challenges of national pluralism.

Even with these analytical difficulties, it is nevertheless possible to readily observe the empirical reality of national pluralism within a larger number of countries across the world than is often assumed, with one account even asserting that ' 90 per cent or more' of existing states cannot be considered mono-nation states (van den Berghe 2006). Based on the Minorities at Risk (MAR) data, Bertrand and Laliberté calculate that there are 126 ethnic groups in 23 countries in Asia, out of which 15 are classified as 'sub-state national groups'; 362 ethnic groups in 43 countries in Sub -Saharan Africa, out of which 4 are sub-state national groups; and 74 ethnic groups in 19 countries in North Africa and the Middle East, out of which 4 are sub-state national groups. This means that there are sub-state national groups in 39 per cent of countries in Asia, 9 per cent of countries in Sub-Saharan Africa, and 21 per cent of countries in North Africa and the Middle East (Bertrand and Laliberté 2010). In very few of these multinational states do sub-state nations receive the constitutional recognition they demand, and where they do, political practice often serves to negate any constitutional commitments as do exist. This suggests that the issue of national pluralism constitutes a constitutional and policy challenge that ought to engage social scientists at a more general level than the interests of area studies specialists who are often the only ones to study this phenomenon in any depth.

\subsection{The modern world of nation-states}

The international order as we know it today took shape with the dissolution of the Western European empires after the Second World War, which saw the creation of many new states in Asia and Africa. With the collapse of the Soviet empire, a number of new states were created.

During these successive waves of state formation, the dominant model was what was described later as 'classical modernist' nation-state building (Smith 1998). The classical 
modernist post-colonial nation-building model sees the sovereign nation-state as the essential condition of modernity (Smith 1983). Based on the general principles of this heuristic blueprint, proponents of the model seek to build territorial, civic, nations corresponding to states through a wide array of techniques, including communications, mass education, political mobilization, and constitution-making, in much the same way as an architect designs a building or an engineer a machine. It takes the distilled experience of nation and state formation in the post-industrial West as the exemplary path to the universal modernity to which they strive. In other words, societies escape feudalism and religious and ethnic primordialism in Asia and Africa by making good copies of the predecessor civic nations and territorial states in the West (Smith 1998).

If those are the broad sociological and historical theses of post-colonial modernism, there are also a number of key normative propositions associated with it. These may be listed as follows. Nations are primarily territorial not ethnic entities. They are made up of political communities constituted by the principle of equal citizenship and civic participation. The nation defined in this way is the wellspring of sovereignty, which constitutes the sovereign state. The nation and the state cannot be separated; they only make sense as a conjoined concept ('nation-state'). Nation-states command the loyalty of their members to the unity of the community, and this is desirable in that it gives coherence and substance to the ideals of democratic participation, civic community, and popular sovereignty. Individual as well as communal disloyalty to the nation-state - for example, in the form of attempted secession can be dealt with by force, and this is in principle ethically defensible, for otherwise both internal and international order collapses. Finally, the intertwining of nation, state, and sovereignty generally favours centralization and unitary forms of constitutional organization (although it is not inconsistent with orthodox, mono-national federalism). In most if not all 
post-colonial states, this model continues to exert a powerful influence on the constitutional imagination of political elites.

By fusing the very notion of democratic modernity with a particular state form, this discourse invested the nation-state with a normative superiority that permitted sub-state nationalisms to be dismissed as backward and revanchist. At the same time, however, in the post-colonial context, state practice did not live up to the civic ideal of the nation-state in a number of ways. In many countries, post-colonial nation-building became not so much a process of modernization as a convenient vehicle for ethnic majorities to consolidate their hold on state power at the expense of minorities. Such states became 'ethnocracies' rather than nation-states reflecting the republican ideals of the French and American revolutions or the liberal principles of the European Enlightenment more broadly (Yiftchael 2006: Ch. 2). Similarly, in many cases, the authoritarian apparatuses of the colonial state continued unreformed, providing the new elites with old instruments of oppressive power now legitimated by the discourse of modernism (Rae 2002).

In these ways, many sub-state nations found themselves trapped within nation-states (and a system of international order that presumed the legitimacy of state boundaries), which had little sympathy with their claims to recognition let alone accommodation. With few exceptions, this continues to be the overriding systemic context that sub-state nations in Asia and Africa have to contend with even today. Yet the widening and deepening of processes of democratization in many of these states reopens the sub-state national question, and demands constitutional responses consistent with the normative commitments of democratization.

\subsection{Democratization and national pluralism}

Most states now subscribe to - or at least claim to uphold - the basic procedural requirements of democracy in the form of periodic elections, and the democratization challenge has moved on to deeper questions of substantive democracy (Whitehead 2002). It is in conceptualising 
the substantive content of democracy however that current thinking in the social sciences has been unable to adequately respond to the multinational conundrum. Due to the dominance of the unitary nation-state, many democratization theorists and policy-makers who are otherwise attentive to the demands of societal pluralism, assume that the demos within states is monistic, whereas the presence of multiple national groups within states demand approaches that recognise multiple demoi (Cf. Stojanović 2010). From that analytical understanding a number of structural and normative implications for constitutional design flows if the democratic ideal is to be fully realised within multinational societies. Unless those questions are attended to, the nation-state's 'crisis of the hyphen' (Anderson 1996: 8) would only perpetuate injustice, instability, and conflict.

\subsection{National pluralism's analytical and normative challenges to traditional democratic constitutionalism}

The first challenge that the empirical reality of national pluralism poses for the dominant unitary conception of the nation-state is that 'nation' and 'state' have to be (re)understood as separate analytical categories (Keating 2001). It follows from the fact of multiple nations within the territory of the state that unless nation and state are disaggregated, the continued assumption that the nation is something that is exclusively associated with the state renders sub-state nations unable to realise their own claims to recognition (Tierney 2006).

Similarly, it is routinely assumed that the unitary nation-state is the sole repository of sovereignty within its territory. In the multinational context, such a monistic conception of sovereignty makes little sense, because the multiple nations that constitute the state's constitutional order would assert their own sources of constituent power. It follows from this that the concept of sovereignty has to be understood in both plural and relational terms. It may not be the case that the unique European Union-style multilevel normative order and pluralised sovereignties are replicable in other parts of the world (Welikala 2015), but the 
division and sharing of internal sovereignty is a common practice in federations and this needs to be amplified in multinational contexts to take explicit account of sub-state nationalities. The relational concept of sovereignty eschews the notion that sovereignty belongs exclusively to either the state or the people in favour of the view that sovereignty is a product of an on-going relationship between the two (Loughlin 1992). This conception suits plurinational constitutionalism especially well, in determining the location and exercise of sovereignty as a constantly negotiated and dynamic political process between the sub-state nations and their host-states.

The nation, separated from the state, has both political and cultural dimensions. It is a form of collective identity defined by a group's shared culture, history, and social institutions; and it is a normative concept in that the assertion of nationhood involves claims to territory and self-government. In both senses but especially the latter, the nation is a space of collective deliberation, decision-making, and self-determination. Individual autonomy only makes real sense within the social context in which choices are made (Kymlicka 1995) and in multinational contexts, the sub-state national society rather than the state-national society is the primary space within which individuals make their cultural and political choices. Democratic constitutionalism's commitments to individual and collective self-determination therefore must extend to sub-state nations and the individuals who comprise them, and must not be limited to conceiving this relationship as being limited to individuals and the traditional nation-state.

However, there are two important provisos to traditional understandings of nationhood in the multinational context. The first is that individuals in the contemporary world can and do often entertain multiple 'national' identities, and this needs to be treated as a reality rather than as a threat. Thus, plurinational constitutionalism must correspond to a reality in which individuals will have allegiances to both sub-state and state national identities, and in some 
cases to regional identities above the state. The second caveat is that the claims to constitutional accommodation of sub-state nations often do not and certainly need not take the form of separate states (Keating 2001: ix). States' fear of acknowledging sub-state national claims to even cultural autonomy stems from the assumption that any recognition of national status inevitably would lead to separatist claims to independent statehood. However, while many sub-state nationalists do make separatist claims for reasons of both strategy and conviction, separatism is not often the primary goal of many within sub-state nations. Instead, they seek accommodation of their national status within the constitutional arrangements of their host-states, in such ways as to give them recognition, representation, and autonomy (Tierney 2006: 18-19, 92-98). This no doubt presents a set of difficult challenges for constitutionalism, but as the experience of both the Western plurinational states as well as a number of recent examples of transitional constitution-making in conflict-affected states have shown, they are hardly insurmountable as technical problems (Ghai and Woodman 2013).

These observations lead to a range of implications for constitutionalism in dealing with the challenge of national pluralism, so as to accommodate sub-state claims to autonomy, recognition, and representation, balanced by adequate reciprocal requirements of state unity. Of these, the most fundamental are the disaggregation of nation from state, and the recognition of multiple national spaces within the state, which in turn demand the design of multilevel constitutional orders with highly decentralised forms of legal authority and political power. It also demands a methodology of constitutional practice that is pluralist, empiricist, pragmatic, flexible, and asymmetrical, or to put it conversely, a constitutional culture that is not hierarchical, rigid, and monistic as most modern liberal constitutional democracies tend to be. 


\section{Rights and citizenship}

\subsection{Introduction}

There is a substantive multidisciplinary literature - from anthropology, law, sociology, politics, philosophy and public policy - that engages with and critically reflects on the relationship between human rights and citizenship and the practical implications of different ways of understanding this relationship. Yet scholarship and public policy debates on human rights and citizenship have broadly been situated in liberal democratic societies, where the predominant concerns have been the integration of migrants and managing national minorities, with the presumption of a trajectory towards legal citizenship in the given nationstate. More recently, the changing conditions of global migration pose challenges for citizenship in liberal democratic societies. Whilst some have argued that we are witnessing the demise of 'national' citizenship, and that instead rights are available to non-citizens through 'post-national' means, others have highlighted that international human rights laws and norms cannot operate outside of national politics. Going further, it has argued that human rights discourses and legislation have actually led to greater inequalities through creating a number of sub-statuses (Nash 2009), and that it is only through citizenship that 'we become human' and can claim rights (Douzinas 2000). In some regions of the world, for example, in the Arab region, there are significant non-citizen populations, where typically there is no route to legal citizenship. Whilst multiculturalism is evident as a discourse at the level of international organizations where respect for minority rights is a normative expectation also being applied to Arab states, it is conspicuous in its absence at the regional and national levels. Where there are forms of minority accommodation (as in Lebanon), this is decoupled from discourses on democratic inclusive citizenship.

This section re-examines the relationship between human rights and citizenship in a comparative frame, starting with a consideration of theoretical understandings of human 
rights and citizenship and the tensions or paradoxes arising between these conceptions. It then explores the tensions and paradoxes between democratic assumptions underpinning international human rights discourses of multiculturalism and trajectories of inclusive citizenship, with regionalized and localized political discourses of minority rights and the nation-state.

\subsection{Between 'human rights' and citizenship}

A significant debate in the field relates to justifications for human rights, and how these justifications are linked to claims of universality. Douzinas (2007: 9) has argued that the term 'human rights' is problematic and paradoxical in that it 'combines law and morality, description and prescription'. The word 'rights' indicates that it is a legal category, whilst the term, 'human' refers to a moral framing of the individual in relation to the law. As human rights can be claims that may not actually be recognized in law, this entails operating in the domain of aspiration as opposed to legal reality - what Douzinas describes as the 'confounding of the real and the ideal characteristic of human rights discourse' (2007: 10). There have also been attempts to define what is meant by 'universality' of human rights. Donnelly acknowledges that some accounts of the universality of human rights are problematic - 'empirically, philosophically or politically' (2007: 281). As a way forward he attempts to delineate different forms of universality where he defends 'functional' and 'legal' accounts of universality, whilst conceding the probable indefensibility of 'anthropological' and ontological' universality. He also talks of an 'overlapping consensus' universality and the notion of a 'relative universality', distinguishing between universality at the level of the concept and at the level of practice (Connelly 2008). In contrast, Goodhart (2008) argues that human rights are a resource for people providing 'aspiration' rather than 'moral truth' and as such the legitimacy of human rights does not come from 'proving' universality. He is troubled by Donnelly's concept of the 'relative universality' of human rights, arguing instead that the 
legitimacy of human rights comes from their global appeal. Clearly however, legitimacy does not stem from universality, rather than the reverse, as this reduces legitimacy to democratic popularity (Connelly 2008), confounding legal grounding with democratic grounding, (Ferrara 2003), and also potentially raising the accusation of 'imperial humanitarianism,4 (Connelly 2007: 298).

In contrast to justice approaches to human rights, 'care' perspectives emphasize connection, concern for relationships and responsibilities, with an emphasis on obligation that does not arise from rights per se. Such perspectives potentially lend themselves to greater sociopolitical and local contextualization, operationalizing human rights in the context of the political interests of the state and its negotiations. This raises a structural problem with respect to the operationalizing of human rights. Whilst human rights claims can challenge existing inequalities, they must appeal to those very structures to make their claims (Benhabib 2005, Douzinas 2007, Soysal 1994). Human rights also act to depoliticize exclusion and conflict by framing these issues as individual claims with a corresponding legal remedy (Douzinas 2000).

Furthermore, whilst human rights discourses suggest that the cosmopolitanization of international law benefits non-citizens, it has been argued that it is only through being fully recognized as a member of the political community, that we become 'human' and can claim our 'human rights'. Whilst legal migrants in Western liberal democracies are often entitled to many civil and social rights, as well as being protected by legislation at the transnational level and sub-nationally, the same cannot be said for refugees, asylum seekers and illegal (or 'irregular') migrants. In this regard, it could be argued that Soysal's conclusion that 'the logic of personhood supersedes the logic of national citizenship' (1994: 164) does not apply to refugees or those of irregular status. It is premature to claim that universal human rights have

\footnotetext{
${ }^{4}$ Connelly (2007) cites Gott, G. (2002). Imperial Humanitarianism: History of an Arrested Dialectic', in Moral Imperialism: A Critical Anthology, 19.
} 
superseded national citizenship 'by disrupting the territorial closure of nations' (ibid.) when we witness, not only the tight control of state borders, but also the differential application of human rights with respect to those irregular migrants, refugees and asylum seekers. Nash (2009) goes further, arguing that the cosmopolitanization of law does not lead to greater equality, and that rather than legally promoting universal human rights, legalization of international human rights law has led to inequality as evidenced through a proliferation of sub-statuses. Critiquing Benhabib, she argues that such political theorizing is at a level of abstraction that is not sociologically contextualized, and so does not engage with what happened in practice. Rather than simply a matter of legal entitlement, claiming rights depends on social structures through which power, material resources and meanings are created and circulated. She conceives of refugees as 'sub-citizens', arguing that this status is created through international law. In addition, Nash (2009) argues that we can witness forms of sub-citizenship even when people hold legal citizenship, but are nevertheless marginalized because of gender, ethnicity, 'race', religion, sexuality or socio-economic class. Taking sociological account of these lived realities is critically important to recognize, and increasingly so with the rise of right-wing populist discourses and movements globally that challenge these 'differences'.

There is a substantial literature on group rights and one of the central debates or paradoxes relates to the very conception of group rights itself. Are rights inherently individual rights or can a group itself be deemed to hold rights, or is it as individuals or the group (Miller 2002)? In addition, are group rights defined as 'human rights' or are they the rights of citizenship? In addition, there is the question of what counts as a 'group', as opposed to people holding certain characteristics. Group rights typically refer to 'external protection' rights - that is rights that an individual of the group can claim for against the state (Kymlicka 1995). However, there are concerns about individuals' rights within the group, especially 
more vulnerable members. Justifications for group rights can be framed as human rights principles or as principles of citizenship. Miller (2002) asserts that typically those arguing to defend group rights make the case that they are fundamental rights of citizenship appealing to equality; language rights for minority groups, or group rights for political representation would be examples. It could be deemed paradoxical that rights for certain groups are based on calls for equality. However, when looking at actual examples, it is evident that calls for group rights are often calls for achieving equality - for example in rights to language, culture, education, and practice of religion.

Another paradox pertains to market citizenship, where citizens are presented with a discourse of having more choice and freedom, yet on the other hand, there is increasing social inequality, political apathy and lack of agency (Root 2007). In addition, in relation to immigration and citizenship, the market is a central force shaping who is deemed worthy of residency and ultimately a route to citizenship. Shachar and Hirschl (2014) use 'Olympic citizenship' to refer to nation-states' strategies of selecting those deemed highly desirable including, for example, the very wealthy, scientists and athletes. Skills-based programmes attest to this trend, as evident in the UK's highly-skilled temporary migrant programme, introduced in 2008, which allows highly-skilled individuals to immigrate, initially for one year, without sponsorship from an employer. On securing employment, this stay can be extended with subsequent entitlement to apply for British citizenship after 5 years (Kiwan 2010). This invokes a moral conception of citizenship on economic grounds, and contrasts with securitization discourses surrounding the concerns of integrating migrants who are unskilled or semi-skilled.

Rather than focusing on the relationship between human rights and citizenship, Isin's (2008, 2009) approach is somewhat different in that he suggests that we need to think in a new way about citizenship. He proposes the idea of 'acts of citizenship', where citizenship is 
not reduced to status or practice, bupt instead has its focus on subjectivity and agency. It has been proposed that refugees and other marginalized groups are participative actors constructing their own identities and acting to mediate their own fate (Nyers 2010) and that these actions constitute 'acts of citizenship' (Isin 2008, 2009). This has been written about in Western liberal democratic contexts, for example, in Canada and the United States, where there have been political movements by groups of irregular migrants, refugees and noncitizens making claims. It could also be argued that this conception of 'acts of citizenship' has resonance in other parts of the world, for example, in the Arab region, where disempowered groups have publically made claims in the context of the Arab uprisings (Kiwan 2014), and also in Lebanon, where there are examples of political and moral agency in Syrian refugees' 'acts of citizenship' in political, cultural and 'moral' domains (Kiwan 2016a). The linking of 'performativity' and 'precarity' as theorized by Butler (2009) makes an argument that the different ways of 'laying claim to public space and to citizenship require both translation and performative modes of expression'. For Butler, precarity is a condition of being at increased risk of violence; furthermore, gender norms relate to this notion. So precarity can refer to a range of vulnerable populations, including refugees, and women refugees in particular. She thinks of performativity not only as 'speech acts', but also in what she calls the 'reproduction of norms', which is necessarily iterative in nature - so that through repeated discourses or acts, a norm is created. She links performativity to precarity arguing that even 'vulnerable' populations lacking the 'right to have rights' can claim its voice and making its claims.

\subsection{Multiculturalism, minority rights and inclusive citizenship}

Whilst citizenship has been an exclusionary concept, academic theorizing and policy approaches illustrate an engagement with developing more inclusive conceptions of citizenship, with a particular interest in citizenship and ethnic and religious diversity. The literature illustrates a range of constructions of citizenship, which can broadly be categorized 
into 'moral', 'legal', 'participatory' and 'identity-based conceptions (Kiwan 2008). Whilst these are certainly not mutually exclusive traditions, they illustrate dominant ways of understanding citizenship in theory and practice. It should also be recognized that the intellectual history of citizenship is a highly gendered conception, where the public sphere is characterized as rational and masculine, in contrast to the private sphere as emotional and feminine (Shafir 1998). 'Legal' conceptions of citizenship draw from the tradition of modern liberal developments in seventeenth century Europe linked to the rise of the modern nation state (Held 1993) and the idea of a 'social contract between 'free and equal' human beings premised on human (male) rationality. Participative conceptions also have a long intellectual history dating back to Ancient Greece, evident in contemporary communitarian approaches to citizenship and civic republican notions emphasizing civic bonds and active participation in the community (Kiwan 2016a). With regards to identity-based conceptions, the twentieth century has been called the 'ethnic' century, as many civil and international conflicts have been framed in these terms (Cornell and Hartmann 2007), and the twentieth first century looks to be continuing in this vein (Kiwan 2016b). One of the central debates in the citizenship literature relates to whether we are witnessing 'renationalization', with negative consequences for immigrants and ethnic minorities (Kiwan 2013). In the context of securitization discourses, it can be argued that immigration and refugee policies, integration policies, and education policies in Western liberal democracies are illustrating a 'restrictive turn' (Joppke 2010, Pacquet 2012, Wright 2008). In contrast, postnational accounts suggest the decline of national citizenship. Despite homogenizing state discourses, individuals and groups contest, construct and negotiate their citizenship identities and practices in relation to official citizenship policies across a range of domains, including, immigration, refugee policy and education policy. 


\section{Political parties and the challenge of democratic representation}

Social progress on a wide range of issues requires that citizens and civil society groups achieve effective representation through democratic channels. Although many types of societal organizations can perform representative functions, political parties have long been seen as vital agents of representation that mediate between states and societies. Parties historically articulated and aggregated diverse societal interests, structured electoral competition, developed policy alternatives, and formed national governments. As such, parties were essential institutions for holding governments accountable to societal interests and preferences.

Nevertheless, the ability of parties to perform these roles has increasingly been questioned in many parts of the world, under both new and established democratic regimes. Although democratic institutions spread to some 60-70 new countries after the mid-1970s in Southern and Central Europe, Latin America, Africa, and Asia, there exists a widespread belief that a 'crisis of representation' is undermining the quality and responsiveness of democratic rule (Mainwaring and Zoco 2007). Even in the long-standing democracies of Europe and North America, signs of representational decay are readily apparent in declining voter turnout, reductions in party membership and identification, rising electoral volatility, and the growth of populist or anti-establishment parties, leaders, and movements (Mair 2013; della Porta 2015).

Although democratic governance involves a mix of representative and participatory practices, some sort of representation is integral to modern large-scale democracies. It is only through acting in concert with others that citizens can hope to influence democratic outcomes. Acting in concert can take a number of different forms, including social movements, civil associations, and political parties, all of which play a role in articulating competing interests and identities. Parties, however, have a central role as representative agents in formal 
democratic institutions, as they are the primary actors who compete in the electoral arena, craft public policies, and organise national governments. As E.E. Schattschneider (1942) famously asserted, 'Political parties created democracy and modern democracy is unthinkable save in terms of the parties.' As such, parties are a natural starting point for understanding contemporary challenges of representation.

Theories of representation derived from the West European experience have long assumed that parties are anchored in, and give political expression to, societal conflicts (or 'cleavages') that structure policy preferences and electoral competition (Lipset and Rokkan 1967; Bartolini and Mair 1990). Parties, in short, are traditionally seen as organizational intermediaries between societal interests and state institutions; they are expected to simplify a plurality of societal interests by aggregating complementary preferences and 'bundling' issues into a reasonably coherent set of rival policy platforms.

With the spread of electoral competition to new countries in the developing world, however, these classic representative functions are often in short supply. Parties are sometimes coercive instruments of previous autocratic rulers (Riedl 2014; Hicken and Kuhonta 2015), or clientelist machines that allow political elites to control popular constituencies by manipulating economic dependency (Kitschelt and Wilkonson 2007; Stokes, Dunning, and Brusco 2013). Parties founded during recent periods of democratic transition are less likely to be rooted in deep class cleavages and more likely to rely on the mass media or charismatic personalities to mobilize support, rather than strong grass-roots branches and organized social blocs (Mainwaring and Zoco 2007). Party systems with such shallow social roots are prone to high levels of electoral volatility, and they are ineffective vehicles for translating societal preferences into public policymaking arenas. That is especially true for working and lower-class groups, which are highly dependent on political 
organization to mobilize their strength in numbers as a counterweight to the more privileged forms of influence and access that elite groups enjoy.

These representational deficiencies are hardly unique to new democracies in developing regions, however. Even in Europe, the historical birthplace of socially grounded, programmatically-defined mass party organizations, 'parties are not what they once were,' as Schmitter (2001) pithily noted. In part, this reflects changes in the social, economic, and cultural landscape on which parties compete. Social cleavages based on class and religion have loosened over time. A wide range of interest groups and activist organizations have emerged alongside and independent of parties to articulate societal preferences and identities. Mass broadcast and social media have partially displaced party organizations from their central roles as agents of political communication, socialization, and electoral mobilization. In this more heterogeneous and pluralistic socio-cultural landscape, citizens have become increasingly detached from party organizations, giving rise to a phenomenon that Dalton and Wattenberg (2000) call 'parties without partisans' (see also Mair 2013). This societal detachment is especially pronounced among the younger generation of voters whose life experiences are far removed from the socio-political cleavages and organizational forms of the industrial era.

Furthermore, as parties' social roots withered they became increasingly professionalized, embedded in state institutions, and dependent on state resources. Rather than representatives of societal interests, parties may come to be seen as collusive and selfinterested political cartels that share in the spoils of public office (Katz and Mair 1995). Cartelization threatens to create an insular and professionalized political caste that is poorly attuned to societal needs and largely unaccountable to them. It also expands opportunities to exploit public office for purposes of corruption, self-enrichment, and influence peddling, practices that seriously distort the democratic process. 
Such rent-seeking practices thrive when the rule of law is weak and institutional checks and balances are inoperative. They are also encouraged when the exorbitant costs of electoral campaigns induce politicians to cultivate ties to private donors, tilting the democratic playing field and undermining institutional responsiveness to popular constituencies (Gilens 2012; Winters 2011). Party competition can thus open channels for private wealth to skew the democratic process by converting economic power into political leverage (see Crouch's part in this chapter). Taken together, varied forms of cartelization, corruption, and rent-seeking drive a wedge between citizens and the political class, and they exert a corrosive effect on citizens' trust and confidence in political institutions (see Vannucci's part in this chapter). Ultimately, they make democracy susceptible to anti-establishment forms of populist backlash.

The erosion of parties' societal linkages has been compounded by their diminished capacity to perform a key historical representative function - that of crafting alternative policy platforms in response to a broad range of societal interests. A gradual programmatic convergence of mainstream conservative and social democratic parties has long been noted in Europe. This process intensified when the post-2008 financial crisis narrowed the programmatic options available to national governments and forced those with sovereign debt crises to adopt orthodox austerity measures dictated by transnational European institutions (Streeck 2013).

In Southern Europe, where the economic crisis was especially severe, political dislocations are strikingly reminiscent of those seen in Latin America following that region's debt crisis and market-based neoliberal reforms in the 1980s and 1990s. Party system upheaval in Latin America was especially pronounced where neoliberal reforms were imposed by labour-based or left-leaning parties that were traditional proponents of state-led development and redistributive social policies (Morgan 2011; Roberts 2014; Lupu 2016). 
Such patterns of reform dealigned party systems programmatically, leaving them without a major party to channel societal opposition to neoliberal orthodoxy. Such opposition, therefore, tended to be channeled outside and against traditional party systems, leading to widespread social protest and the eventual rise of populist outsiders or new 'movement parties' on the left flank of mainstream parties (Yashar 2005; Silva 2009). Similarly, the adoption of orthodox austerity measures by mainstream center-left parties in the early stages of the Southern European crisis triggered widespread social protest and the rise of new, anti-establishment populist or movement competitors. Paradoxically, as Mair (2013) suggested, a course of action that was 'responsible' in terms of securing international market integration made parties less responsive to - and representative of - their domestic constituencies.

Too often, citizens respond to failures of representation by withdrawing from active democratic participation, as evidenced by declining levels of partisan identification and voting turnout in many countries. In much of Europe, however, citizens have also lent support to farright nationalist or populist parties that are hostile to globalization, transnational institutions, and ethnic or religious minority and immigrant communities. Parties that cater to such exclusionary forms of nationalism may advocate forms of 'welfare chauvinism' that defend traditional social programs while narrowing their pool of eligible beneficiaries. A version of such right-wing populism recently triumphed in U.S. presidential elections, where Donald Trump capitalized on economic insecurities, cultural resentments, fears of globalization and immigration, and widespread disillusionment with the two-party establishment.

As Donatella della Porta points out in her section of this chapter, however, other societal responses are possible. Social movements, for example, often emerge in the political void created by deficits in institutionalized political representation. By articulating issue positions or societal values that mainstream parties have neglected, social movements can transform the policymaking agenda, realign electoral competition, and give voice to new or 
marginalized social groups. Typically, they do so in extra-institutional arenas through diverse forms of social protest or 'contentious politics' (McAdam, Tarrow and Tilly 2001).

Social movements, however, need not remain on the margins of democratic institutions. Movement organizations and activists often work within established parties, or even found new 'movement parties' that carry their agendas into electoral and parliamentary arenas (della Porta, Fernandez, Kouki and Mosca forthcoming). In the process, they may realign or reconfigure national party systems. Such was the case with the Green parties spawned in the 1980s by European environmental, peace, and women's rights activists. Examples from Latin America include the Workers Party in Brazil, which was founded by labour and community activists, and the Movement Towards Socialism (MAS) in Bolivia, which gave partisan expression to a range of indigenous, peasant, and community-based movements (Madrid 2012). More recently, the indignados anti-austerity movement in Spain set the stage for a new movement party, Podemos, which challenged the programmatic convergence of mainstream parties. Podemos and other movement or leftist parties in a number of countries have repoliticized economic policymaking around issues of inequality, austerity, social citizenship, and workers' rights, expanding the range of policy debate in the aftermath of the post-2008 global financial crisis.

Similarly, a plethora of civil society actors are performing interest articulation and representation functions that parties once monopolized. Many civic groups work with parties and local governments to shape the policymaking agenda and respond to social needs. Reforms to decentralize government have sometimes facilitated these public-private partnerships, opening new channels for grass-roots participation by community-based civic networks. In many cities community organizations are playing an important role in budgeting, programme design, policy implementation, and the monitoring of public agencies (Baiocchi, Heller, and Silva 2011; Heller 2001). Such pluralistic forms of civic engagement provide 
opportunities for societal input that are a vital complement to the activities of party organizations.

Other types of institutional reforms can also enhance parties' responsiveness to societal concerns. Serious efforts at campaign finance reform and the regulation of mediabased political advertising might reduce the incentives and opportunities for corruption, shielding the democratic process from the influence of private wealth. Likewise, independent judiciaries and electoral agencies are vital to safeguard against abuses of power and maintain the integrity of the electoral process. It should be recognized, however, that institutional reforms can have unintended consequences or potential trade-offs between conflicting goals. Primary elections, for example, may give citizens greater voice in the selection of party candidates for public office, but as seen in the U.S. they can also inflate the costs of elections and make party leaders dependent on wealthy private donors to finance internal campaigns. Moreover, primaries may encourage polarizing or populist tendencies in party systems, or even provide access to party leadership positions by populist outsiders, as seen in Donald Trump's stunning displacement (and eventual cooptation) of the Republican Party establishment in the USA.

Ultimately, modern democracy has seen a proliferation of new societal actors in the public sphere, but it has yet to discover a substitute for party organizations in a number of essential representative functions. For better or worse, parties continue to structure electoral alternatives, form governments, and shape policy initiatives. The ability of parties to craft meaningful programmatic alternatives at the national level would be well-served by coordinated international efforts to govern global markets. Indeed, vigorous advocacy of such coordinated efforts could offer a new opportunity for parties to craft progressive platforms that are clearly differentiated from the technocratic convergence of mainstream parties around market orthodoxy. In the meantime, both traditional and emerging parties face the challenge 
of giving institutional expression to the broad range of societal actors and interests that are clearly dissatisfied with conventional forms of representation.

\section{Expertise and Democracy}

Since the beginning of the Scientific Revolution, science and expertise have acquired large roles as facilitators of democracy. The rise of experimental science, it is argued, gave citizens a new model for witnessing rulers' claims and holding them to higher standards of public justification (Ezrahi 1990). By the late nineteenth century, scientific knowledge, interpreted and communicated by experts, provided indispensable rationales for political action, ensuring that governments would not stray outside the limits of reasonableness and that publics, too, would agree on the need for new agenda items and policy decisions. Progressive politics at the turn of the twentieth century accepted and largely celebrated the growing delegation of policy responsibility to experts. Despite the shocks of two world wars and subsequent pessimism about technology's power to reduce human autonomy and freedom (Habermas 1970), faith in government based on facts and evidence has only grown.

Many developments over the past 100 years bear out the belief that scientific knowledge increases civic participation, encourages interstate collaboration, and enhances the quality of public reason. Nineteenth-century divisions based on race and gender gave way to biological and sociological knowledge that established the equality of all human beings and laid the foundation for equal political treatment of all. ${ }^{5}$ More recently, environmental and health

\footnotetext{
${ }^{5}$ Petitioners' briefs for two of the most progressive decisions by the Supreme Court of the United States-Muller v. Oregon, 208 U.S. 412 (1908) (legitimating limits on working hours to protect women's health) and Brown v. Board of Education of Topeka, 347 U.S. 483 (1954) (holding that educational systems separated by race could not be equal) — both argued in part on the basis of social science evidence.
} 
knowledge spurred the formation of national, and to some extent global, 'epistemic communities' (Haas 1990) on issues from biodiversity to pandemics and climate change.

Yet, faith in the democratizing influence of enlightened knowledge has long been troubled by countervailing doubts: in particular, the threat that superior expertise creates hierarchies of non-accountable power and excludes the demos from choosing its own purposes. Moreover, if public facts are made in ways that reinforce prior constellations of power, dominance, and injustice (Foucault 1980), then how can democracy realize its promises of accountability and self-governance?

Constructivist studies of science and technology have added new dimensions of concern, replacing a naturalistic account of scientific truth, in which science unproblematically mirrors nature, with perspectives that treat science as a mode of representation and interpretation (Felt et al. 2016). How such representations achieve and maintain authority becomes highly relevant to analyses of democracy and law. Work in the field of science and technology studies (STS) shows that knowledge about the world and norms for inhabiting the world are coproduced (Jasanoff 2004) — that is, our factual depictions of how the world is cannot be disentangled from our understandings of how we should live with the fruits of that knowledge. On this view, scientific claims are neither neutral nor universal but rather reflect their conditions of production. Facts, put simply, are endpoints of social and political struggle (Latour 1987). And if facts are established through politics, then the hope that facts can create a level playing field for politics seems more mirage than reality.

\subsection{Paradoxes of Progress}

Does more knowledge lead to greater social progress? Is the Enlightenment promise that civic maturity will grow along with scientific understanding still valid, or is a more complex restatement warranted? What is the evidence on either side, and how should 
democracies take note not only of what science delivers but also of the limits of public knowledge? Further, if knowledge is a form of power, do means exist in contemporary democracies to ensure that this power will be accountably wielded?

It is widely accepted today that investments in science and technology are necessary if societies are to remain healthy and viable, whether by escaping from entrenched poverty and its assaults on human dignity or by promoting growth in jobs and economic opportunities. Those investments increasingly include not only research driven by scientists' curiosity about fundamental aspects of nature, but also science answering to governmental demands for useful knowledge. By the late twentieth century, the world's collective knowledge-producing capabilities included large amounts of what came to be called Mode 2 science (Gibbons et al. 1994): applied, transdisciplinary, multisited, and reflexive or conscious of its own valueladenness.

Technological developments enabled economic growth and reduced poverty, as dramatically illustrated in the rise of the 'Asian tigers'-Hong Kong, Singapore, South Korea, and Taiwan. Yet, the Tigers, along with neighboring countries such as Indonesia, Malaysia, Vietnam, and Thailand, embraced very different pathways to involving publics in governance. China's emergence as a global economic superpower only magnified the lack of congruence between the welfare benefits of scientific and technological activity and the spread of democracy.

In Western democracies, as well, fractures appeared in the alignment between knowledge and social harmony. First, contradicting the presumption that increasing knowledge resolves ambiguities and provides more reliable grounds for politics, more science opened up new frontiers of doubt and uncertainty. In this period of 'reflexive modernization' (Beck 1992), people used science to question the very facts that science produces in such abundance. The results range from what Ulrich Beck termed 'organized irresponsibility' — the 
lack of accountable rulership - to 'science for hire,' with claims generated to serve parochial political interests. Increasing privatization of knowledge-making produced pockets of nonaccountable expertise: models and algorithms that govern vast tracts of economic and social policy were shielded against critique by intellectual property laws and secretive corporate practices. Additionally, in most technologically advanced societies, expert knowledge related to military strategy remained largely outside of democratic supervision. ${ }^{6}$

Second, in spite of the contingency of policy-relevant expert knowledge, science in the abstract provides a powerful deskilling discourse with which politicians deflect democratic criticism by accusing publics of scientific illiteracy. Canonical cases include protests against childhood vaccination; rejection of genetically modified crops and foods; skepticism toward the expert consensus around anthropogenic climate change; and, especially in the United States, rejection of evolutionary theory in favor of beliefs grounded in the Bible. Some commentators ascribed Britain's referendum vote to leave the European Union in June 2016 ('Brexit') to an ignorant rejection of economic expertise. Similarly, Donald Trump's surprise 2016 victory in the US presidential election was seen as a win for ignorant populism. Together, these examples support a 'deficit model' of citizenship (Wynne 1994), which holds that a knowledge-deficient demos cannot be entrusted with the rights and obligations of selfrule.

Third, especially in the United States, where political disputes often spill over into litigation, the law's claims to impartial authority and commitment to reason have been compromised by accusations of scientific illiteracy. Judges, like other members of the lay

${ }^{6}$ For example, the civilian death toll from US drone strikes has been contested, and independent organizations making such estimates have little faith in numbers generated by the government. Charlie Savage and Scott Shane, 'U.S. Reveals Death Toll From Airstrikes Outside War Zones,' New York Times, July 1, 2016. 
public, are frequently charged with lack of scientific understanding. More insidiously, legal institutions are themselves complicit in ratifying a bright-line distinction between facts and values, and the corollary assumption that fact-finding must precede normative judgment. This is most apparent in the discourse of the 'law lag,' which declares that law is unable to keep up with the rapidity of scientific and technological advances and thus constantly arrives too late in its efforts to resolve situations of moral ambiguity or indeterminacy created by those developments.

These phenomena highlight the need to complicate the relationship between knowledge and social progress. A growing literature points to the varied and subtle ways in which tacit assumptions about the right ways to organize collective behavior impinge on and shape a society's approaches to producing shared knowledge, reasoning, and technological applications. Those underpinnings, because tacit, tend to be reproduced and reaffirmed by largely unreflective institutions. Therefore, although robust democracies continually give rise to new expert bodies, new technologies, and new knowledge-based policies, many deeper commitments to forms of politics rarely get exposed to critical scrutiny. These constitutional dimensions of political culture shape the conditions of possibility for modern politics, both democratic and authoritarian.

\subsection{Cultures of Public Reason}

Technological determinism is the commonplace notion that possibilities unlocked through material inventions drive human progress. There is, however, nothing deterministic about how societies respond to technological innovation. To be sure, technologies with enormous implications for society sometimes disperse quickly throughout the global marketplace — such as cars, cell phones, computers, and to some extent contraceptives. But on a great variety of technologies, from fossil fuels to agricultural biotechnology, neither lay nor 
official responses have converged transnationally, even when there is strong scientific consensus about the nature of the risks and benefits.

The public uptake of expert claims is a phenomenon to be understood in its own right in comprehensive accounts of democracy and the rule of law. 'Civic epistemologies' (Jasanoff 2005), or public ways of knowing, refer to the institutionally stabilized ways in which citizens assess the public reasoning of powerful state organs. States differ in the practices by which they generate public knowledge, select and authorize experts, subject epistemic claims to public testing, and construct the very idea of objectivity in public discourse. These practices affect the credibility of expert claims. It matters, for instance, whether public knowledge is built as a 'view from everywhere,' with all interested parties gathered around the same table, or as a 'view from nowhere,' constructed through clashes among interest groups so as to produce claims that appear to stand above and outside of identifiable interests. The more inclusive practices of 'view from everywhere' reasoning have led to markedly fewer public knowledge controversies than the 'view from nowhere' approach. The latter, however, encourages a more skeptical style of citizenship, with lay publics more willing to generate their own expertise and question claims of higher epistemic authority.

No theory of political legitimacy questions (as yet) that sovereign states have a right to organize their public knowledge practices in accordance with their own cultural understandings of how to constitute relations between experts and citizens. If, however, divergent practices lead to different appraisals of the state of the world — whether the matter is climate change or plant genetic modification or threats to public health - then there could be democratic justification for epistemic subsidiarity, that is, an acknowledgment that different assessments of the same evidence may be allowed to coexist without needing to be standardized or brought into complete harmony. How and under what circumstances such subsidiarity may be tolerated remains an open question for political theory. 


\subsection{Epistemic Democracy: A New Constitutional Form?}

The paradoxes and divergences identified above are likely to increase as technical expertise makes its way into new domains of decision making and is disseminated through the ever more accessible digital medium. The proliferation of social media allows wider access to information, empowering popular sovereignty, but it also encourages the formation of bubbles or 'echo chambers' among like-minded individuals, displacing deliberative exchange across varying belief systems.

Democratic societies are not insensitive to these challenges, and developments over a half century indicate growing awareness that the workings of government must include forms of public epistemic engagement. However, institutions for delivering on this insight, as well as the capacity to forge closure in situations of deep epistemic conflict, have not necessarily kept pace. Even in cultures committed to open access, pressures may form to exclude participation that rulers see as unreasonable. In turn, the moves by which such exclusions are made are themselves culturally conditioned.

To sum up, 350 years since the beginning of the Scientific Revolution, modern societies find themselves caught in novel binds about the role of knowledge in fostering democracy and the rule of law. The wide dissemination of knowledge and knowledge-making capabilities has not necessarily fostered well deliberated, let alone wise or even rational, judgments. Fundamental challenges remain in the form of increased splintering and privatization of knowledge making, the loss of trust in expert bodies, the opacity of transnational organizations, the persistence of power imbalances between rich and poor, and (not least) the unreflective uses of science to reinforce dominant problem framings that exclude genuinely challenging alternatives. 


\section{Participatory democracy in the neoliberal era}

In speaking of democratic deficits and paradoxes in our current era, it is impossible not to address the issue of citizen participation. Partially as a result of disappointments with democratic institutions, we are living today through a veritable 'participation revolution.' The idea that citizens ought to be at the centre of governance has, since at least the late 1990s, become a central part of mainstream policy thinking. Although many - if not most - of the ideas about participation emerged with social movements and the political Left, enthusiasm for 'citizen participation' today spans the political spectrum (as well as the globe) and is today widely endorsed and promoted by mainstream public policy experts, pro-market actors, as well as social movements. From deliberative polls to plebiscites, to e-governance, to participatory budgets and all manner of citizen forums, it is hard to find a democratic government today that does not invoke citizen participation in some form. Today we are witnessing a new political moment in which citizen participation is no longer the assumed domain of outsiders but has become widely encouraged, if not directly mandated, by governments and multilateral agencies. As Matt Leighninger (2006) writes in his enthusiastically titled 2006 book, How Expert Rule Is Giving Way to Shared Governance And Why Politics Will Never Be the Same, 'In the 20th century, public life revolved around government; in the 21 st century, it will center on citizens.' Similarly many others discuss the dawning of an era in which citizens have come to participate in all sorts of matters previously reserved for government bureaucrats and politicians. To talk of citizen participation today is to address something being invoked by Podemos in Spain, by the Bolivarian Revolution in Venezuela, as well as by the World Bank and the European Union.

Yet, despite the enthusiasm, citizen participation is today deeply paradoxical, and in this small section we briefly explore what we see as its premises and limits. Participation, generally speaking, is today understood as a compelling way to gather governmental input, 
build trust in government, and create communities of engaged citizens. More sanguine promoters also hold the view that participation, properly instituted, can help solve all kinds of modern-day problems of governance and politics. Yet, citizen participation today is fundamentally compatible with neoliberal tenets. It has emerged at the time of neoliberal reforms and government rollbacks and in some cases been deployed with the purpose of legitimating those reforms. It is, moreover, it is based on the idea of the individual, selfresponsible citizen who solves problems without recourse to politics, movements, or sectoral representation. Mechanisms of citizen participation very seldom address the fundamental questions of power and inequality at the heart of the neoliberal project. This is not all, however. Participation does bring together communities of equals under a logic of inclusion, which causes tensions in neoliberalism. Participation can also bring to life ideas of collective, shared interests that cannot be dealt with at all within the neoliberal frame, which sees politics is just about the sum of individual needs and demands. Participation can come to mean very different things in different places, depending on the power of movements, associations, and unions to shape the experience. These are the very actors that current understandings of participation do not recognise.

\subsection{The history and development of participation: the 'perverse confluence,' top-down influences and travel}

Although numbers are difficult to come by, most experts agree that the number of experiences of citizen participation have exploded in the last two decades across the global North and the global South. As Archon Fung suggests, part of the difficulty in estimating the extent of participation is that 'the forms of participatory innovation are often local, sometimes temporary, and highly varied' (Fung 2015: 514). But all indications suggest it is a very major trend. There is general agreement that we are living through what Caroline Lee, Michael 
McQuarrie, and Edward Walker (2015: 7) have called a 'participatory revolution.' Today, they note, 'across the political spectrum, increasing citizen voice is viewed as a necessary counterweight to elite power and bureaucratic rationality.' If contemporary ideas of participation emerged among social movements in the 1960s, these ideas were first appropriated by mainstream policy makers two decades later. Caroline Lee, who has studied what is today known as the 'Public Engagement Industry,' dates its appearance to the late 1980s but notes a tremendous growth in the 2000s. Demand for services by the International Association for Public Participation, for example, tripled between 2005 and 2008 (Lee 2015). In addition, participatory instruments now quickly travel the world as processes of 'fast policy transfer' (Peck and Theodore 2010).

Dagnino, Olvera, and Panficci (2016), in the context of Latin America, have described a 'perverse confluence' between left democratizing projects and multilateral agencies around the desirability of participation. This resulted from the meeting of genuine 'democratizing projects that were constituted during the period of resistance to authoritarian regimes' and 'neoliberal projects' at the end of the 1980s. 'In effect,' they write, 'they are based on the same references: the construction of citizenship, participation, and the very idea of civil society' (Dagnino, Olvera, and Panficci:16). All manner of New Left parties, movements and NGOs turned away from Leninist practices and took a 'local' and a 'social' turn, with a central focus on ideas of civil society and participation (Castañeda 1993: 200). This new thinking was eclectic, influenced by sources as wide as debates with European New Left, Liberation Theology, and Radical Pedagogy. Throughout Latin America in the 1990s, there were demands and claims from social movements and new progressive actors who sought to reform the state and deepen democracy through participation. This discourse ranged from the Zapatistas, to the Civil Society Assembly in Guatemala, to local administrations run by the Workers' Party in Brazil, to the Movement for Socialism in Bolivia, among many others. At 
the same time, agencies like The Inter-American Development Bank, USAID, the World Bank, and other bilateral and multilateral donors like DFID (UK), CIDA (Canada), UNDP, and major foundations like Ford, Kettering, Rockefeller, and MacArthur had all adopted the language of civil society and participation. For one indicator among many, at the global level, the World Bank has invested $\$ 85$ billion in development assistance for participation in the last decade (Mansuri and Rao 2013, cited in Fung 2015: 514).

Citizen participation in the global North follows a similar time-line and similarly wide cast of characters. There has been a sea-change in thinking about governance and the role of the citizenry since the late 1990s. The original interest in participation, of course, dates to social movements like Students for a Democratic Society, in the US, and post-68 mobilizations in Europe. But it took disappointment with New Public Management and ideas of the minimal state for these ideas to move to the mainstream. In the early 2000 s, in particular, there was growing concern about the quality of democracy and democratic participation in industrialized democracies. At the same time as 'anti-globalization' activists expressed their desire for a more genuine global democracy, and innovated through the practices of NGOs and new movements - sometimes directly inspired by Global South movements like the Zapatistas or Brazil's Landless Movement-mainstream scholars and government officials worried as well. While the tenor was slightly different in Europe and in North America, the worry about declining citizen engagement, growing apathy, mistrust in government, and atomization was shared. As a result, there were a number of reforms and policy initiatives in several countries meant to encourage participation and bring citizens back into the work of government. Some have called this broad move a turn to 'Public Governance,' even if there is no consensus yet for the reforms and policies intended to increase citizen participation. But the trend is very clear. For North America a survey from 2009 found that almost all cities responded that they provided 'opportunities for civic 
engagement in community problem solving and decision making' and that nearly threefourths of them had instruments in place for citizen decision-making in strategic planning that year $^{7}$. In Western Europe the figures are similar, and several countries now mandate citizen participation as part of recent local government reforms ${ }^{8}$. Bingham, Nabatchi and O'Leary (2005) catalogue and describe the tools of this new governance, which include deliberative democracy, e-democracy, public conversations, participatory budgeting, citizen juries, study circles, collaborative policy making, and alternative dispute resolutions that permit citizens and stakeholders to actively participate in the work of government.

\subsection{Compatibility with neoliberalism: marginal experiments, self-responsible citizens, and conflict-free deliberations, and without Sectoral Representation}

While they range in format, new forms of participation share some common features. They are open, and inclusive, and place 'ordinary citizens' at the centre. That is, they are not mediated by what are nowadays described as representatives of 'the old ways,' like unions, social movements, or political parties. Participation is not supposed to be conflictive, as it promises a win-win for all: governments get better input, citizens are heard, new solutions are dreamed up, and a more encompassing and inclusive sense of the common good emerges out of deliberation for all involved. By and large, participatory experiments have brought new participants to the demos. Though there is significant variation, there are significant successes in attracting non-traditional and vulnerable participants to forums that in some instances have surpassed the capacity of social movements in creating inclusive spaces. There is evidence of

\footnotetext{
${ }^{7}$ National League of Cities, Making local democracy work. Goodwin explores the data further to show 'that a large majority (69 percent) had citizens serve on ad hoc task forces and a fairly high percentage of cities held neighborhood meetings (48 percent) and town meetings (39 percent)' (Goodwin 2014: 253).

${ }^{8}$ Recent research in Southern Europe highlights that most municipalities 'have developed considerable participatory activity' (Font, della Porta and Sintomer 2014: 42).
} 
democratic learning, and some evidence of increased civic capacity that has been spurred by these.

Nonetheless, there is reason to worry, and critical scholars have begun to point to the ways that participation is part and parcel of neoliberal reforms (Hickey and Mohan 2004), with some, like Pablo Leal, referring to 'the buzzword of the neoliberal era?' (Leal 2007). It is more than the fact that participatory democracy has spread as governments have retrenched, or that local governments have, in some cases, introduced participation to improve the fiscal management of dwindling resources.

The first worry is that these experiments often take place at the margins of the state apparatus, without significant government reform, and without transforming the functioning of state institutions. They invoke the language of empowerment without devolving significant decision-making to participants. Many experiments are introduced 'from above' and do not allow for participants to define the terms of participation itself. Many of these experiments particularly consultative forums - do not wield decision-making power, or if they do, they do not wield decision-making power over significant decisions, such as economic policies. These experiments are fundamentally not able to challenge inequalities that are one of the principal threats to democracy. Second, there is the worry that participation paves the way to a depoliticization of the public sphere. Participation today emphasises important characteristics of the neoliberal citizen: self-regulation, responsibility for individual problems, and a nonconflictive partnership with the state (Li 2005). In this formulation people are 'conceived as individuals who are to be active in their own government, and shifting responsibilities for problems to individuals and communities' (Ferguson 1990). As the state pulled out of the realm of social policy, these participatory citizens are charged with shouldering the burden. And third, there is the move away from sectoral representation. It is not uncommon for promoters of participation today to frame their appeals as a way of going beyond unions, 
social movements, neighborhood associations, or interest groups, and placing emphasis on 'regular citizens.' There is no role for such organizations. This changes the structures of collective negotiation between the organizations and the public authorities with a direct system of decision-making. But this emphasis on direct voice can conflict with, and disempower, associations and movements formed around conflicts. Thus, the worry by Frances Cleaver and many others, that a central postulate of the thinking on participation today is that while there is a lot of emphasis on 'getting the techniques right,' 'considerations of power and politics on the whole should be avoided as divisive and obstructive' (Cleaver 1999: 598).

\subsection{Tensions with neoliberalism, and recapturing democracy from below: associational power, camps and other demands}

The idea of citizen participation in matters of common concern has very clear origins in social movements and progressive instincts. Yet, participation today is a different phenomenon. If participatory democracy's scope has expanded, its emancipatory dimension has all but disappeared. The question, rather than whether participation is neoliberal, is what its potential to tension the neoliberal project might be. More and more, democracy appears to spread while its meaning seems to be ever more modest. There are more ways than ever to participate democratically today, but the range of decisions within the reach of the demos seems narrower than ever. 'We are all democrats now,' writes Wendy Brown (2015), but, as she also poignantly asks, 'what is left of democracy?'

While today's very widespread institutions of citizen participation by themselves would not have much to offer much to address the current challenges to democracy as detailed elsewhere in this chapter, they are not seamless parts of the neoliberal project either. There are some important ways that citizen participation can come to be in tension with 
neoliberal projects. First, is that while it is difficult to track with any precision because participation is so ubiquitous, we can say that some participatory experiments, like Participatory Budgeting, have brought new participants to the demos (Baiocchi and Ganuza 2016). Though there is significant variation, of course, and in some instances there are significant successes in attracting non-traditional and vulnerable participants to forums. The evidence is clear that this is not the case all of the time, but there are important examples of forums with otherwise disenfranchised participants, whether we are speaking of urban denizens in Brazil, lower caste women in India, or formerly incarcerated or undocumented immigrants in New York. ${ }^{9}$ This is not a trivial accomplishment, especially in that these are formally spaces of equals, where all, in principle, are allowed equal voice. And in some of these instances, forums have surpassed the capacity of social movements in creating inclusive spaces. There is also evidence of democratic learning, and some evidence of increased civic capacity that has been spurred by these spaces (Talpin 2012). And of course, in a world of increasing inequality and segregation, these can be very significant spaces.

Finally, there is recurring finding by the scholarship that what participation comes to mean is ultimately contingent on local configurations of actors. Whether we are speaking of the Andes, of Brazil, of Southern Europe, or India, one recurring and robust finding has been that social movements, political parties, and unions can push citizen participation to be more transformative, more empowering, more responsive to local context, and more tied to fundamental decisions that matter ${ }^{10}$. A comparative study of cities that adopted participatory budgeting reforms in Brazil in the late 1990s, for example, showed that the outcome of the implementation of the same reform in otherwise similar contexts was conditioned by the

${ }^{9}$ There is a vast literature based on case studies. Some exemplars include Su (2017); Rao and Sanyal (2009) and Baiocchi (2005)

${ }^{10}$ This is a finding in Font, Della Porta, and Sintomer (2014); in Baiocchi, Heller, and Silva (2011); in Baiocchi and Ganuza (2016); in Van Cott (2009); and in many other works. 
presence of these collective actors. In particular the quality of democratization heavily depended on the autonomy of social movements to provide a counterweight to participatory forums. From that vantage point movements were able to push the limits of participation and force greater inclusion as well as more meaningful decision-making. Participation, in fact, continues to be a platform of social movements and other collective actors around the world who see in it the potential to deepen democratic institutions and foster social change (see della Porta's part in this chapter). Yet, these are the very actors that are excluded in current modes of citizen participation.

\section{The judiciary as a challenger}

\subsection{The changing role of the courts}

Since the 1960s, the social and political role of judges and courts has dramatically changed, prompting a shift in the balance of powers within democracies. Although the intensity and the timing of this transformation has differed from one country to another, the judicial branch has been endowed with new functionalities, including social progress, the fight against corruption, identity recognition, the 'free market' and antitrust regulation. In a large variety of countries, from India to South Africa, Brazil to Italy or Germany, courts have become a central and relatively autonomous arena for the mediation of political, economic and social interests. The ubiquitous rise of the judiciary in democracies has triggered optimist scholarly and political discourses on the emancipatory and democratic potential of this new path. Many have viewed judicial empowerment as fulfilling the promises of liberal democracies on equality and rights, taking 'law' out of the hands of bureaucrats and politicians and bringing it back to the 'people' and civil society. With the active support of international and regional organizations involved in promoting 'democracy and the rule of law', a standard of the 'independent judiciary' has consolidated based on equal access to 
courts, fair trial and professional judges. It has become increasingly valued to settle the hard cases of democracies and to act as a substitute to the failures of representative politics and to the pitfalls of international realpolitik. Yet, the progressive potential of this rights- and courtscentred approach is ambivalent. While the rise of the judiciary has opened up new avenues for social progress, it has, in a 'boomerang effect', contributed to the further weakening of the traditional channels of representative democracy. In addition, the instrumental role given to courts in the rise of neo-liberal modes of governance now threatens their capacity to live up to the new democratic and social promises that they have generated over the past decades.

\subsection{An alternative use of rights}

For long, the 'rule of law' and the judiciary were viewed by progressives as belonging to a broader block of socially and politically conservative elites that protected economic freedoms including property and freedom of contract, thereby impeding the unfolding of more progressive social and economic deals. In various Western countries, however, the 1970-80s brought an important change as new claims for equality, often framed as minority rights, have been pursued through litigation strategies before courts. In the wake of politicization of the public debate in the late 1960s, new conceptions of law and of courts emerged within the legal professions in Western Europe, North America and in part in Latin America. New social movements have contested the monopoly of trade unions and left-wing parties over the realm of progressive politics, in part through the progressive discovery of the emancipatory potential of rights' claims. The world of human rights' activism that has emerged around transnational NGOs such as Amnesty international, Human Rights Watch, Oxfam or FIDH, philanthropic foundations, and professional lawyers has come to consider 'courts and rights' as a key avenue to fulfill the political and social promises encapsulated in liberal democratic founding declarations. Following the successes of civil rights' movements in 1960s America, 
advocacy groups have embraced forms of 'cause lawyering' in domains such as gender equality, the inclusion of indigenous people, or the nondiscrimination of sexual minorities. To some extent, the judicial avenue has therefore become a surrogate for democratic participation for minority groups structurally marginalized in the political field.

In turn, rights and courts have been profoundly transformed. Historically framed in the liberal tradition as political and symbolic in nature, texts such as the European Convention of Human Rights, national Constitutions or bills of rights, and principles such as rule of law and equality have turned into justiciable legal entitlements. A new blend of 'constitutionalism' empowering constitutional courts with the task to protect 'fundamental' individual rights. In the process, new rights have emerged, including privacy and data protection, nondiscrimination, and human dignity, which are now justiciable before national and international courts. In addition, the weakening legitimacy of legislatures has prompted new delegations of powers to constitutional courts extending the scope of their judicial review into new domains, including political campaigning, same-sex marriage, and affirmative action policies. In parallel, the various Clean Hands' operations against political corruption in Italy, Spain, or Brazil solidified a coalition of civil society movements, new sections of the media as well as moral entrepreneurs around the defense of judges and prosecutors as the best controllers of 'political virtues' (Pizzorno, 1998). In turn, these changes have triggered a transformation of the judicial branch itself. Under the lead of regional or international organizations that have promoted higher 'standards' of independence and forms of judicial cooperation across national borders, courts have made a drift away from the state-centric conceptions of their role. In parallel, thanks to the development of legal aid and the diffusion of class actions, they have become more accessible and responsive institutions, thereby opening more ways to use judicial arenas as a venue to settle political and social conflicts. 


\subsection{Judicialization and its (dis)contents}

Yet, this dramatic change in the role of courts has prompted a wider shift in the allocation of political authority within representative democracies. Against all naïve narratives of the judicialization as a process of democratic empowerment, the politics of counter-majoritarianism is itself deeply embedded in and driven by political and social elites. At times, they may even be an essential lever through which threatened political and social elites attempt to preserve their hegemony and lock in their policy preferences and worldviews, as Ran Hirschl (Towards Juristocracy, 2004) has argued in the case of the rise of constitutional courts in countries such as South Africa or Israel. Emblematically, the recent anti-corruption inquiries in Brazil and the related impeachment procedure against the democratically-elected president, Dilma Rousseff, have been led by conservative political elites. The role of legal elites is equally ambivalent. While the rise of courts has also increased the statute of the judicial and legal professions, the latter are not necessarily more diverse, socially and ideologically, than the elected representatives (Bellamy, 2007) ; in the end, they may act more as 'gate-keepers' than as 'transmission belts', narrowing down social claims into a pre-existing set of legal alternatives (and, thereby, sidelining potentially innovative arguments and causes).

Because of the very individualizing of features of rights' claiming, judicial petitioning has also brought its own contribution to processes of 'depoliticization'. The development of a 'rights' talk' that has hampered public debate has often led to an 'impoverishment of political discourse' mostly centred on individualism and liberty at the expense of more collective causes and solidarity campaigns. While it has helped concretize the claims for 'equality before the law', the rise of courts has further undermined the political relevance of the traditional arenas of representative democracy. The gradual prevalence of a liberalconstitutionalist conception of the judiciary has in turn fuelled the development of new forms 
of populism that have pointed at the judges' lack of social and political legitimacy. Revamping old criticisms of the 'gouvernement des juges' and old concerns over the 'counter-majoritarian difficulty', new waves of contestation of judicial review and constitutionalism have emerged as shown by campaigns in the UK led by UKIP and some sections of the Conservative Party against the European Court of Human Rights (ECHR) or by the recent 'political backlash' led by a variety of a variety of African states against the jurisdiction of International Criminal Court. Last but not least, the capacity of this 'new constitutionalism' to secure citizen's political and civil rights is nowadays profoundly challenged by the massive increase of States' repressive capacities to face post-September 11 terrorist threats -from the 2001 Patriot Act to the ongoing 'state of emergency' in France and Turkey (see Peterson's section in this chapter).

\subsection{Courts in neoliberal politics}

The promises raised by the rise of rights, however, face an ever bigger challenge given the instrumental role that courts have gained with the rise of neo-liberal economics. With the general retreat of state interventionism in the economic realm, courts have become the new pivot institution of the development of 'competitive market', together with regulatory agencies, themselves shaped most often on a quasi-judicial model. Under the umbrella of the 'regulatory state' championed by neo- and ordo-liberal doctrines of market regulation, courts have increasingly instrumental. The liberalization of trade and the promotion of free markets have been fostered by the creation of specialized economic courts such as the Court of Justice of European Union or the World Trade Organization appellate body, thereby marginalizing alternative understandings of other diffuse interests such as social protection or human rights. Segments of the public administration, business elites and interest groups have used them to insulate economic freedoms from the dynamics of democratic politics, securing a 
constitutional statute for economic freedoms through judicial or quasi-judicial bodies such as regulatory or competition agencies. Courts have become powerful lever to reduce governments' restriction to competition and undermine cartelized industries and state monopolies The European Court Justice (ECJ), arguably the most effective international/regional court in the world, provides a clear example. While economic freedoms have gained a very powerful stance in Luxembourg, their dominance has prompted a selective protection of human rights, favoring the rights that were instrumental to the building of a Single Market such as non-discrimination, and sex equality while disregarding or dismantling others such as labour rights, which remain weakly protected at the EU level.

This connection between neoliberalism and courts has brought large companies and transnational interest groups in closer contact with courts. With the rise of multinational companies and the increasing international flows of trade, finance, and production, a growing market for legal services has emerged that transcended the traditional national boundaries of legal systems. Starting in the United States and the United Kingdom in the 1970s, a new organizational model began to spread internationally, that of global law firms with branches in Europe and, later, in the new BRICS markets, especially in Asia. These mega-law firms, such as Baker \& McKenzie (with 77 branches in 47 countries) or Clifford Chance, now provide full and standardized services to their corporate clients ranging from transnational legal counseling to world-wide legislative and administrative lobbying. Positioned across the globe, they have the resources to pursue long-run interests in changing the state of the law through litigation and they are able to play across national and sector-specific legal domains, seizing fault lines, opportunities and loopholes. The recent cases of the Panama papers or LuxLeaks have further exemplified the brokering role corporate lawyers may play in globalized markets. Together with their clients, they engage in judicial forum-shopping, circumventing state regulations in domains like taxes or social rights. This autonomization of 
the international field of lex mercatoria has led to an unprecedented development of commercial arbitration and similar forms of private justice shielded from public scrutiny and forms of accountability. Most trade liberalization treaties now include arbitral mechanisms so-called Investment State Dispute Settlments (ISDS) - which circumvent states' judicial apparatus. On the whole, the increasing capture of this new judicial terrain of market regulation by big law firms and large interest groups has contributed to strengthen the political capacity of their clients and further undermined states' capacity to promote an agenda of 'social progress'.

Courts and rights have progressively been integrated into a larger neo-liberal compact, thereby tuning down the initial promises of equal civil and social rights. Ever since the mid1990s, international organizations such as the International Monetary Fund or the World Bank, as well as law-and-economics scholars, have come to view the independence of the judiciary and the protection of economic rights such property rights and freedom of contract, as a key lever in the transformation of emerging countries into competitive markets. Similarly, in western democracies, courts have played an instrumental role in the rise of the neoliberal mode of governance that combines regulatory agencies, private actors' enforcement of legal norms and a certain style of dispute resolution (so-called 'adversarial legalism'). This judicialized mode of governance has proved to be a powerful challenger of the more cooperative and neo-corporatist style of government typical of Welfare State politics (Kelemen,2011). With its limited administrative capacity, weak redistributive policies, and salient non-majoritarian institutions including courts, regulatory agencies such as the Directorate General for Competition and central banks, the European Union is the most emblematic case. Beyond the fact that this new governance scheme arguably obscures decision-making, it also contributes to circumvent the scope and the efficiency of 
representative politics, turning various intermediaries, be they consultants, lobbyists, advocacy coalitions or lawyers, into de facto political actors.

In the end, the rise of rights and courts is highly ambivalent. Their progressive role in fulfilling the liberal and social promises written down in the grand declarations and bill of rights of liberal democracies is nowadays undermined by the instrumental role that courts and lawyers play in the rise of neoliberal policies and the demise of the Welfare State. In ways akin to what Luc Boltanski and Eve Chiapello have described as The New Spirit of Capitalism (2006), the progressive potential of rights' claim for recognition and autonomy has been in part incorporated and diverted into the neoliberal compact in ways compatible with its development. And yet, this tipping back of the judiciary is far from complete and still encounters a variety of professional and political counter-movements.

\section{The construction and governance of democratic political spaces in times of perceived crises}

A central paradox of democracy is between conflict and consensus. 'Democracy implies dissent and division, but on a basis of consent and cohesion. It requires that the citizens assert themselves, but also that they accept the government's authority. It demands that the citizens care about politics - even if not too much' (Diamond 1990: 56). Consequently, a healthy democratic state invites its inhabitants into its decision-making and implementation processes, even dissident inhabitants. So in order to retain their legitimacy liberal democracies are constitutionally committed to allow dissent. The public spaces for assembly and freedom of speech are essential elements in democracies and these spaces of contention, according to liberal constitutions, must be protected. The conundrum lies in that while domestic dissent must be allowed, governments are determined to steer this dissent in ways that do not fundamentally threaten the political and economic order. The spaces for the 
manoeuvre of political challengers must be protected without jeopardizing the rule of law. Demonstration rights must be made secure but political violence on the part of challengers, such as terrorist attacks on refugee centres or mosques, must be rigorously policed. In other words, institutional actors meet the perceived threats of oppositional forces with actions designed to 'steer the conduct of civil society' (Loader 2000: 344). Repression or policing contention is a dispersed mechanism for the governance of the dominant political and economic order. Dissent is governed, by sheer coercive force or by less strong-arm and subtle means, in order to maintain the status quo (Peterson and Wahlström 2015).

Policing contention is typically thought of as exercised at the national scale, and in many cases this is correct in so far as it concerns the steering, that is, law-making and coordination of repressive capacities. However, since 11 September 2001 the US-defined 'war on terror' has dramatically extended the geo-political scope of the governance of dissent to the global scale and with this extension clouded the traditional distinction between domestic threat and foreign threats. Post-September 11 has witnessed an unparalleled international cooperation and intelligence sharing between police authorities and security services and private corporate intelligence agencies in this new situation for the governance of dissent.

In response to terrorist actions or the threat of terrorist actions, numerous democracies across the globe enacted anti-terrorist legislation, such as the Patriot Act in the US and the Prevention of Terrorism Act in India, which have radically expanded the repressive powers of the federal government thereby infringing on the civil rights of assembly and protest (Cole 2003). Abdolian and Takooshian (2002: 1446) point out that 'historically, during times of crisis, it has been natural for democratic nations, including the United States, to temporarily abridge individual liberties in ways that would never be considered in more halcyon times'. The rule of law, in Agamben's (2005) understanding, becomes lawless. For example, the 
USA Patriot Act of October 2001 dramatically expanded the definition of terrorism to include what the Act defined as domestic terrorism, thus enlarging the number of activities to which the Patriot Act's extended law enforcement powers could be applied. For example, animal rights and ecological organizations could fall within its reach making it potentially a 'felony to, among other things, 'deter' the business activities of industries engaged in the exploitation of animals and natural resources' (Eddy 2005: 262). These changes in the statutes have, according to Eddy, boosted the governance capacities in some states to protect economic interests and threaten to significantly raise the costs of involvement in nonviolent environmental protest.

Furthermore, policing theorists have warned that democratic societies have progressively shifted towards becoming 'surveillance societies' where 'surveillance displaces crime control for the efficient production of knowledge useful in the administration of suspect populations' (Ericson 1994: 139), thereby more and more and effectually extending in liberal democracies the legal scope of repression away from respect for the constitutionally protected rights of individuals to encompass collectives of individuals. For example, since September 11 and further accelerated in face of the threat posed by ISIL (Islamic State of Iraq and the Levant), security services are increasingly targeting Muslim communities as suspect populations. By casting a wide net in their counterterrorism measures, security services have introduced a 'religious profiling', such as Trump's anti-Muslim executive order, which in effect risks criminalizing Muslims per se (Peterson 2012). Counterterrorism policing in many Western European countries now gives priority to what are called preventive strategies, which in effect extends the scope of repression from political dissidents to targeted communities and away from the constitutionally protected rights of individuals, which is a cornerstone in the rule of law in liberal democracies. 
Political actors - both social movements and political parties - are found across the political spectrum; not all political actors are benign nor democratically progressive. We have in addition the basic democratic paradox of majoritarian rule in liberal democracies in which majorities can suppress minorities and, with the support of an electoral majority, the processes of democracy can be turned back or even overturned; for example, the current cases of Hungary, Poland and Turkey.

In the wake of the fiscal crisis in 2008 and the waves of refugees seeking entry into Europe far-right extremist movements and far-right parties are mobilizing the 'losers' in ever increasing numbers across Europe, as well as the US. Democracies, through an ordinary 'free and fair' election, can take a turn away from the rule of law. In Hungary in 2010 Viktor Orbán's Fidesz Party won 53 per cent of the vote and a seat bonus big enough to give it powers of constitutional amendment, moving toward what Orbán himself has called an 'electoral revolution'. The speed and the scale of the changes have indeed been revolutionary. The new 2011 Constitution and its enabling acts have turned what are supposed to be politically neutral bodies such as the Constitutional Court, the Central Bank, and the offices of the Ombudsman and the Public Prosecutor into arms of the ruling party. In short, according to Rupnik (2012: 133), 'Orbán and his lieutenants have downgraded or done away with the checks and balances that are widely considered essential for the rule of law'. If you add to this an act that creates a state agency meant to ensure 'media objectivity', thereby undermining the public space for critical opposition, you have the main components of an authoritarian drift in the construction of political spaces and the governance of dissent.

The ruling Law and Justice Party (PIS) in Poland passed laws in 2015 that make it more difficult for the Constitutional Court, to overturn any of the government's decisions. The Court itself refused to follow the new laws, which it declared were unconstitutional - a textbook definition of a constitutional crisis (see Vauchez this chapter) - and a full-blown 
domestic democratic crisis has erupted. KOD, a new pro-democracy movement established in 2015, put an estimated 250,000 people on the streets for a protest in May 2016. The Council of Europe's Venice Commission, which focuses on constitutional rights and the rule of law, issued a report condemning the moves. On the border of the EU in Turkey we find a similar authoritarian drift in the governance of dissent. President Erdogan has gradually been reversing two decades of democratic progress in Turkey and had in 2016 pushed through a tough anti-terrorism law — condemned by the EU — that was used to target even democratically minded opponents, when placing under arrest the pro-Kurdish HDP party leaders together with ten MPs. In short, after the failed coup in July 2016 the ruling AKP party has launched draconian measures to silence dissent. Tens of thousands have been purged in the effort to rid the civil services and education system of alleged Gülenists reaching far beyond the proponents of the putsch to target other dissidents.

In the 2014 European elections in the UK the Eurosceptic far-right party UKIP achieved first place with 27.5 per cent of the total vote marking the first time since the 1910 general elections that a third party garnered the largest share of the votes. That election paved the way for the 2016 advisory referendum when, led by UKIP and some Conservative Party members, 52 per cent of the votes were cast in favour of leaving the EU. Negotiations for a Brexit are underway.

While the developments in Hungary, Poland, Turkey, and the UK are perhaps the most dramatic, these movements and parties have found varying traction within civil societies and among electorates across Europe. The response by many citizens across Europe to the socalled refugee crisis has been to cast their votes for authoritarian, nationalist, xenophobic and anti-EU parties. These far-right parties are flourishing, now further fuelled by Trump's presidential election victory in the US. During his campaign Trump had openly and repeatedly attacked basic democratic and constitutional norms; not least his support for 
physical violence as a response to political disagreement and his virile attacks against critical journalists. These political developments are unsubtle reminders that majoritarian rule must be tempered by robust constitutionalism that protects the civil rights of minorities and defends free speech.

Events, whether these are terrorist attacks or the perceived threat of terrorism, fiscal crises, or a refugee crisis, demonstrate the fragility of democratic processes in so-called new democracies as well as in consolidated democracies. Democratic processes can be rolled back. The still on-going fiscal crisis is challenging democracy from both a technocratic and a populist direction. In Greece and Italy, democratically elected but insolvent governments have succumbed under pressure from the Eurozone and the European Central Bank and ceded (temporarily) vast policy-making powers to unelected experts. According to Donatella della Porta (forthcoming) a shared element of the recent anti-austerity protests she studied in Latin America, Eastern Europe and South Africa was the discontent at what was perceived as a violation of acquired entitlements by a small and corrupt oligarchy of businessmen and politicians.

The authoritarian tendencies we are witnessing across the globe appear to marry well with the 'liberal state'. In the wake of the global fiscal crisis della Porta (2015) identifies a concomitant 'crisis of responsibility'. Committed to protecting neo-liberal markets, for example with bail-outs of banks, which more or less undermines government finances, liberal governments are unable to protect their citizenry from the deleterious effects of global neoliberalism. Facing the real challenges from an aggrieved and concerned citizenry, dissent is increasingly governed in more repressive ways.

In conclusion, democracy is under siege and from a number of fronts, not least from the state itself. The responses of governments across the globe to real and perceived crises, even of governments that with some justification claim to be 'liberal' and 'democratic', 
provide substance to Giorgio Agamben's (2005) portentous warning that we have entered a 'permanent state of exception'; 'the state of exception has become a paradigm of government today' (Agamben and Raulff 2004: 609) and security has become the political vernacular. The existence of derogation-like clauses permits states to suspend the protection of certain basic human and civil rights thereby undermining meaningful political action. For example, after the failed coup in Turkey mid-July 2016 a state of emergency was decreed and has since been prolonged for an indefinite period. The decree has allowed the Erdogan government to shut down the Internet in eleven Kurdish cities and restrict access to social media services throughout the country; the top executive of Turkey's most influential opposition newspaper together with nine other staff members have been likewise incarcerated.

Declaring war on terror the Bush administration invoked a global state of emergency to wage infinite war on an indefinite enemy. The war on terrorism is highly ambiguous, more or less infinite; the Pentagon originally named the 'war against terrorism' 'Operation Infinite Justice' (cited in Kellner 2007, p. 626). The present 'permanent state of exception' should, Agamben indicates, be understood as 'a fiction sustained through military metaphor to justify recourse to extensive government powers' (Agamben and Raulff 2004: 610), which can be introduced to cope with political dissent more generally — we see increasingly the conjunction of sovereign power and the police in the governance of dissent in contemporary democracies. As Ian Loader and Neil Walker (2007: 7) point out, the state itself must be civilized - 'made safe by and for democracy'. States can only do so by engaging with all of its inhabitants, even the poor and dispossessed, in constitutionally protected spaces for democratic dialogue and dissent regarding the exercise of its power. A vigilant and engaged citizenry offers the sole protection against the potential excesses of democratic states. It is upon their shoulders that the responsibility for 'taming states' lays. Rule by the people must also be rule for (all) the people. 


\section{Internet and the paradoxes of democracy and the rule of law}

The Internet has become a central feature of contemporary societies. According to the International Telecommunication Union (ITU), at the end of 2016 nearly half of the world's population had an Internet connection whilst in 1995 it had been less than one per cent. The bulk of internet users can be found in developing countries, with 2.5 billion users compared with one billion in developed countries in 2016. The rise of the Internet has led several commentators to describe the last two decades as the 'cybersociety' (Jones 1998), 'Internet society' (Bakardjieva 2005) or the 'Internet age' (Castells, 2015). These views give special attention to digital media as a major driving force shaping the structures of modern 'networked' societies.

The Internet has facilitated new forms of structuring the ways humans relate to one another, and influence one another. The profound impact that the internet has had and continues to have in modern societies has triggered a growing literature on the effects it has on democratic processes. This section discusses how communication technologies are shaping social movements, activism and other forms of political participation.

In the context of deliberative democracy, true democracy requires citizen participation and engagement through active discussion with other citizens (Habermas, 1996). The Internet brought the hope of an expanded and new public sphere, capable of embracing a broader set of ideas and a broader set of citizens.

The high rate of Internet penetration, low cost of online communications and global reach, have brought attention to the possibilities of the internet as a source of citizen empowerment (Benkler, 2006). In this respect, the Internet holds the potential to generate 'communicative power' (Dutton and Peltu, 2007), bringing participatory opportunities to traditionally 'voiceless' agents to express their demands - a platform where individuals and 
communities are able to express their needs and desires. In addition, the combination of an increased access of citizens to government information and the possibilities of electronic voting, enables new types of internet-based engagement with democratic processes. Moreover, the dissemination power of the Internet brings a new dimension to citizen journalism and grassroots documentary-making, significantly altering relations of power in the media (Goode, 2009). The importance and appeal of the empowering potential of the internet in democratic processes is multifaceted and undeniable.

However, less is known about the negative impact that ICTs can have in democratic processes. Some arguments include the potential of further social polarization, with the Internet becoming a public sphere for the educated and affluent (Streck 1998; Dahlberg 2001); the dangers of information overload and misinformation (see the viral widespread of fake news reported during the 2016 USA presidential elections and elsewhere) ${ }^{11}$; and the way in which such rapid widespread of radical collective action can lead to violent conflict escalations.

The possibility to build stronger democracies in times of digital media and the Internet is still not well understood. It has already been argued that technology and democracy have had a 'deeply ambivalent relationship' (Barber, 1998).

Thanks to emerging online platforms, citizens find new ways to engage in the democratic discourse. The African continent, wherethe extensive use of cell phones has been coupled with a more recent and massive interest in social media, provides an example of the development of comprehensive an internet-based tool that allowed people to gather crisisrelated data in Kenya (see case of Ushahidi) ${ }^{12}$. These online platforms, designed to be used

11 http://www.nytimes.com/2016/11/18/technology/fake-news-on-facebook-in-foreign-elections-thatsnot-new.html?_r=0

${ }^{12}$ http://www.un.org/en/africarenewal/vol24no1/ushahidi.html 
by ordinary people, allowed users to report a violent incident through text message, e-mail or web submission, and to portray the information on an online map ${ }^{13}$. These modes of citizen monitoring have reportedly performed better than mainstream media by gathering more cases of violence and covering wider geographic areas. The ability of citizens to write their own news and monitor events has deep implications on political voice (Hindman, 2009). Such valuable examples also raise questions about the dangers of lowering the gates of free-flowing information and the risks of misinformation; with the absence of gatekeepers it becomes more difficult to establish the accuracy of shared information.

Along with ordinary citizens, political leaders are also increasingly reliant on ICTs, and the 2004, 2008 and more recently the 2016 USA presidential elections are testimony to that. Newspaper and television-based electoral campaigns have been largely replaced by those conducted through social media. Twitter becomes a key tool used by political parties and candidates to inform the public about their stances and express their grievances. A recent study has shown that 62 per cent of US citizens get their news via social media (Gottfried and Shearer, 2016).

Activists and dissenters are also adapting the ways in which they communicate, collaborate and protest to the possibilities brought by new online platforms (Kelly Garrett, 2006). The speed at which ICTs are able to spread information about a particular event or concern, accelerates the reach of support communities across geographical areas, leading to rapid intensification of social movements. Activist mobilizations in Tunisia, Egypt, Spain, and elsewhere have been partly credited to the creative use of social media platforms such as Facebook and Twitter.

\footnotetext{
${ }^{13}$ Ushahidi's software has been adapted to other geographical areas, to help rescue earthquake victims in
} Haiti, and monitor violence in the DRC, South Africa and Gaza 
Making political statements through non-violent direct actions such as activism and civil disobedience constitute important acts of democratic participation ${ }^{14}$. These forms of democratic participation have taken new forms with the evolution of ICTs, especially through social media. As stated by Youmans and York: 'Information technologies have become indispensable to reformers, revolutionaries, and contemporary democracy movements. They serve as venues for the shared expression of dissent, dissemination of information, and collective action' (Youmans and York 2012: 315). In this respect, there is a considerable amount of research that has pointed out the ability of ICTs and in particular the internet to nurture the development of collective identities across dispersed populations, to the extent that can lead to collective action. Many studies have found evidence of protest groups that have formed and acted collectively on the basis of concerns shared through social media and internet-enabled blogs and websites (Castells, 2015). The growing belief that 'The Revolution Will Be Twittered' comes together with predictions of a 'revolution 2.0' and a 'Facebook revolution'. Nevertheless, in response to such perceived power, others have questioned the ability of social media to bring about radical change. Such cautions are based on the observation that social media activism involves low risk and weak ties (Gladwell, 2010) leading to 'slacktivism' (Mozorov, 2010) and an illusion of meaningful participation with political matters with minimum effort such as joining a Facebook group or adding your name to an online campaign.

These are not, however, static relationships and interactions, and Internet-enabled technologies, especially social media are surrounded by a changing ecosystem of actors and institutions. They are constantly evolving, and so their governance and use also evolve.

\footnotetext{
${ }^{14}$ Although civil disobedience remains controversial given that it violates and ignores existing laws.
} 
The Internet has facilitated the adoption of more decentralized, non-hierarchical organizational forms of democracy. However, at the same there is reference to a "crisis in democracy' visible in the general disengagement of young people from traditional forms of political participation. Youth and their relationship with digital media deserves particular attention, as they have been key drivers of important contemporary online-enabled movements such as the Arab Spring, Anonymous and Wikileaks.

Hacktivism has become one of the ways for civil society to communicate ideas and promote the principles of democracy and enhance individual freedoms using technology. The role of hacktivism has gained visibility in recent years and speaks directly to the issue of power, technology and society. Hacktivism, or the actions of politically motivated hackers, emerge from the marriage of political activism and computer hacking. They differ from other types of hackers in their motivation, as they are driven by the pursuit of social change, rather than profit. Wikileaks and Anonymous have become some of the best known hacktivist networks.

Wikileaks started operating in 2006, offering a platform for whistle blowers to expose secret material anonymously. Its purpose is to achieve higher levels of government transparency by exposing sensitive files to the public, thereby subjecting them to societal scrutiny. Their existence and high levels of activity has ignited worldwide debate on the extent to which sensitive information should be publicly available.

Anonymous has been described as a collective of 'hackers, technologists, activists, human rights advocates and geeks' who organize collective actions online and offline that 'advance political causes' but are also organized 'for sheer amusement' (Coleman 2012). Anonymous advocates a culture of grassroots democracy based on an anti-leader and anti- 
celebrity ethic, 'decentralized non-hierarchical modes of interaction' and a 'commitment to consensus' (Coleman 2011). ${ }^{15}$

Electronic disobedience and hacktivism are new controversial forms of civic participation, and are likely to have a continued and growing impact on the Internet and the world. They represent a way for civil society to participate in global politics through the new public sphere, communicate their ideas and promote the principles of democracy using the technology. Through their actions, hacktivists have raised important questions related to the issue of freedom of expression and the freedom of information. By running whistle-blower campaigns against government practices, hacktivism is challenging the existing structures of power as well as the traditional channels of challenging power (such as independent press and traditional NGOs and CBOs).

Driven by a clear ethic and norms, some hacktivists disrupt the status quo of politics, holding politicians accountable by bringing their actions to the media spotlight. However, there is still a need to differentiate between different types of hacktivists - as they vary in their motives, ethical adherence and willingness to engage in illegal or legally ambiguous activities - while some forms of hacktivism are clearly illegal other types remain in the grey area of transgression. In this respects, the delimitation over boundaries of what are socially acceptable protest activities, remains under scrutiny. What is becoming clear, is that the criminalization of political dissent can have long-term consequences in the understanding of

\footnotetext{
${ }^{15}$ It became better known in 2010 through their support of Wikileaks, by launching a series of Distributed denial of service (DDoS) attacks to shut down the websites of several companies that disabled donations to WikiLeaks.
} 
political participation and the emergence of new configurations of social movements (Bosch, $2017)^{16}$.

In summary, it is important to understand the intricacies of the complex, dynamic and multifaceted relationship between online platforms and new forms of democratic participation in order to ensure that they assist the democratic process by encouraging open debates while engaging the public and delivering reliable information.

\section{Progressive social movement and the crisis of responsibility in late neoliberalism}

Social movements affected, affect and can be expected to affect the development of states in democratic as well as non-democratic regimes (della Porta 2014). While not all movements have been oriented to expand citizens' rights, progressive social movements have struggled for civil, political and social rights, also addressing the meta-issue of what politics and democracy are about. Social movements on the Left have in general challenged a definition of progress as optimization of economic conditions or economic growth, reflecting instead on issues of justice and democracy.

\subsection{Social movements and citizens' rights}

Historical work on the evolution of citizens' rights has stressed the role of mobilization from below in achieving them. Civil, political and social rights developed with the mobilization of the labour movement, bringing about institutional change. At the origins of democracy lies 'the entrance of the masses into history' (Bendix 1964: 72). In the protest campaigns for the widening of citizenship rights, other models of democracy were also

${ }^{16}$ Bosch, T. (2017). Twitter activism and youth in South Africa: The case of\# RhodesMustFall. Information, Communication \& Society, 20(2), 221-232. Chicago 
conceptualized and practised, including direct, horizontal, and self-managed democracy. Social rights began then to be discussed as indispensible conditions for a true enjoyment of political rights (Marshall 1992: 28). As with the labour movement in the past, so more recent movements became arenas for debating and experimenting with different conceptions of democracy. The protest movements of the late 1960s were interpreted as an indication of the widening gap between parties and citizens, and of the parties' inability to represent new lines of conflict (Offe 1985). The anti-authoritarian frame, central for these movements, was articulated in claims for 'democracy from below'. Democracies of councils and selfmanagement were also discussed in the workers' movements of those years. In part, these conceptions penetrated the democratic state through reforms that widened participation, in schools, in factories and in local areas but also through the political recognition of movement organizations and the 'right to dissent'.

\subsection{Social movements in the neoliberal juncture}

As liberal democracy remained dominant, an understanding of contemporary challenges requires an assessment of the mechanisms whose functioning was needed in order for liberal democracy to be legitimate. Three such mechanisms were necessary. First, liberal democracies needed functioning political parties as actors that could implement the principles of electoral accountability. Second, majoritarian conceptions of democratic decision-making needed a nation-state as defining the border of the demos in whose name and interest decisions were made (see Keating's part in this chapter). Third, and more subtly, even though liberal democracy did not call for social equality, it still relied upon the assumption that political equality would reduce a social inequality that threatened the very principle of free access to political rights (see Crouch's part in this chapter). The liberal form of democracy developed, that is, in contexts characterized by three elements: well-established welfare states, 
party democracies, and the full sovereignty of the nation state. At the turn of the millennium, these conditions have been challenged as neoliberal globalization as well as other evolutions in contemporary democracies have produced a shift of power from parties (and representative institutions) to the executive; from the nation state to international governmental organizations (IGOs); and from the state to the market, which also implies a shift from welfare state to warfare state. Even though these are neither complete nor natural or irreversible trends, they do challenge the legitimacy of to the (neo)liberal vision of democracy, that is based upon an elitist conception of electoral participation for the mass of the citizens and free lobbying for stronger interests, along with low levels of state intervention (Crouch 2003: 5). While the weakening of political parties, nation states and welfare states challenges some definition of democracy, they might have produced some opportunities for other conceptions of democracies, less reliant upon electoral accountability (Rosanvallon 2006: 8).

Social movements have long been considered as children of affluent times, or at least of times of opening opportunities. The protests against first the austerity policies in the global South and then the Great Recession in the European periphery defy these expectations, developing in moments of declining opportunities at both economic and political levels (Silva 2009; della Porta 2015, 2017). What is more, in many parts of the world, these movements have been able to radically change the party system, promoting the emergence of new actors, sometimes able to experiment with new policies (Roberts 2015; della Porta et al. 2016). If there are potentials for change in a progressive direction, the challenges for a progressive politics from below remain high; in the mobilization capacity of a fragmented social bases, the development of a collective identity and solidarity, and the construction of a sustained organizational structure. 


\subsection{Class structures and the social base for protest: the challenge of fragmentation}

Social movement studies have seen recent changes in the social structure as not particularly conducive to mobilization. Not only have processes such as deindustrialization and migration weakened the structural preconditions that had facilitated the emergence of a class cleavage, particularly in the working-class model of collective action, but recent developments have also jeopardized citizens' rights through poverty, unemployment, and job insecurity. Anti-austerity protests have challenged the new social movement paradigm. Sometimes called 'multitude' or 'precariat', those who protested against austerity represented coalitions of various classes and social groups that perceived themselves as losers of neoliberal development and its crisis.

Precariousness is certainly a social and cultural condition for many movement activists (Standing 2011). Overwhelmingly present in protests is a generation (that in Portugal defines itself as 'without a future') characterized by high level of unemployment or employment in ill-paid and un-protected. Young people took the lead in the Arab Spring, and those affected by the financial crises mobilized in different forms in Southern Europe. These young people are not those which have traditionally been described as losers. They are rather the well-educated and the mobile, which were once described as the 'winners' of globalization but no longer perceived themselves as such.

Together with them, however, are other social groups that have lost most from the neoliberal attacks to social and civil rights, from public employees to retired individuals. Once considered as the most protected social groups, they have seen their rights continuously reduced, becoming, precarious themselves in terms of their life conditions, losing fundamental rights such as those to health-care, housing, education (della Porta 2015). Similarly, blue-collar workers of the small but also large factories, shut down or at least in danger of being shut down, have participated in the wave of protest. With high levels of 
participation by young people and well-educated citizens, the anti-austerity protests brought into the street a sort of (inverted) ' $2 / 3$ ' society of those most hit by austerity policies. Traditional workers participated, but so did retired people, unemployed and precarious workers (although these were more present in other types of protests). Therefore, the protests brought together coalitions of citizens with different socio-biographic backgrounds, but united by their feeling of having been unjustly treated.

The capacity of protest waves mobilize this broad but heterogeneous basis has been varied, however, with very different opportunities for coalition building as well as international networking (della Porta 2016).

\subsection{The construction of collective identities: the challenge of individualism}

Recent progressive movements have to face a particular challenge in building collective identity. If neoliberalism strengthened a liquid culture, destroying old bases for personal, collective and political identity through forced mobility and related insecurity (Baumann 2000), identification processes among anti-austerity protestors seemed to challenge the individualization of liquid society as well as its fear and exclusivism, calling instead for state intervention and inclusive citizenship, with the re-emergence of a social criticism of capitalism. Defining themselves broadly - as citizens, persons, or the 99 per cent - activists of the anti-austerity activists developed a moral discourse that called for the reinstatement of welfare protections, but they also challenged the injustice of the system (della Porta 2015). A call for solidarity and a return to the commons has been juxtaposed to an unjust and inefficient neoliberal ideology. Referring often to the nation, as basis of reference of a community of solidarity, they however developed a cosmopolitan vision combining inclusive nationalism with recognition of the need to look for global solutions to global problems. Differently from the global justice movement, which had presented itself as an alliance of 
minorities in search of a broad constituency, the anti-austerity movements have constructed a broad definition of the self (della Porta 2015). Backward looking, the anti-austerity protests called for the restoration of lost rights, vehemently denouncing the corruption of democracy. However, they also looked forward, combining concerns for social rights with those for cultural inclusivity. As precariousness, as lost security about life development itself, spread from young unemployed and under-employed to large social groups of once protected, identification with the overwhelming majority in the society might provide some certainty.

What remains open is however the capacity of these movements to build new collective identities. The recognition of the great diversity within the movement does not seem sufficient to build long term solidarities. The populist reasoning, as reconstruction of an idea of the people (Laclau 2005), is still at early stage.

\subsection{Movements and political legitimacy: The challenge of power}

Social movements active against austerity policies are embedded in a crisis of legitimacy that takes the particular form of a crisis of lack of responsibility towards citizens' demands (della Porta 2015, 2017). However, rather than developing anti-democratic attitudes, protesters claim that representative democracy has been corrupted by the collusion of economic and political power, calling for participatory democracy and a general return to public concern with common goods. Given the extremely low trust in existing representative institutions, these movements have addressed requests to the state, but also experimented with alternative models of participatory and deliberative democracy. Acampadas became places to prefigure new forms of democracy. In comparison with the global justice movement, the declining confidence in representative institutions is reflected in the weakening of the search for channels of access to public decision making through lobbying or collaboration. Even if there is still a search for politics, its traditional forms are mistrusted and autonomous ones 
explored. In this sense, these movements are not anti-political but rather propose a different deliberative and participatory - vision of democracy that they prefigure in their own organizational forms. Deliberation through high-quality discourse rather than charismatic power is called for as a way to find solutions to common problems. In the presence of an institutional system felt as more and more distant, a direct commitment is asked for. Deliberative and participatory conceptions and practices of democracy are combined with an emphasis on the direct participation of the citizens rather than through networks of associations.

Very successful in addressing the public and at times capable of sudden and dramatic political effects, these protests have been based upon new strategies with however still uncertain capacity for organizational resilience and the stabilization of collective identities.

\subsection{Progressive versus regressive movements: Some concluding remarks}

Donald Trump's victory in the 2016 US presidential election has been widely perceived as a sign of the triumph of regressive over progressive movements. Similarly, the Brexit referendum has been taken as an indicator of a wave of parochialism that threatens to wash away once-dominant cosmopolitan sentiment. It should come as no surprise that moments of crisis also engender political and social polarization. In fact, social movements have frequently emerged simultaneously on both the Left and the Right. In the crisis of neoliberalism, counterforces (similar to what Polanyi had called counter-movements) emerged, developing in two directions: some were progressive, seeking to expand citizens' rights within an inclusive, cosmopolitan conception, and others were regressive, yearning for a bygone order in which only a restricted number of insiders were protected. However, it remains to be seen whether the Brexit or Trump campaigns can truly be conceived of as populist movements, rather than other forms of populist politics. 
If we look indeed at the forms that this discontent takes on the Right, they appear to be very different from the ones we can observe on the Left: not only with respect to the sociopolitical content of their claims, but also with regard to organizational models. Research on right-wing populism has long identified a cultural demarcation - with cosmopolitanism on the one side and xenophobia on the other - that separates the political Left from the Right (Kriesi et al 2012). This is all the more the case today. Additionally, politics on the Right is characterized by a specific organizational form that builds on strong, personalized leadership rather than citizen participation. This clearly differentiates it from progressive movements.

The question of under which political conditions a regressive countermovement can develop remains to be addressed. Research on progressive movements has clearly shown that the specific characteristics of discontent under neoliberalism and its crisis are influenced by the political responses to the great recession, particularly by the strategies of centre-left (especially party) politics. Notably, research on anti-austerity protests in Latin America has shown that the most destabilizing waves of protests occurred where party politics failed to offer channels of anti-neoliberal dissent, as all major parties supported neoliberal policies (Robert 2015). A similar situation seems to be emerging in Europe, where the consequences of repositioning on the Right in terms of (exclusive) visions of social protection seem all the more dramatic when the Left is perceived as championing free markets and lacking a significant alternative.

\section{Social progress, economic factors and political conditions}

At the end of the $1980 \mathrm{~s}$ and into the beginning of the $21^{\text {st }}$ Century, all of the political conditions for a qualitative leap forward in social progress seemed to be in place. The triumphal declaration of 'the End of History' was regarded by many as credible. It implied that no longer did citizens (except for the diminishing proportion of them living in 
autocracies) have reason to expect any radical challenges to their established institutions. Liberal democracy, the rule of law and social equity had become solidly entrenched and mutually supportive. The Wall dividing East and West had fallen. The Soviet Union had collapsed and fragmented into new republics. The countries of East-Central Europe were well on the way to a successful transition to democracy, following the trajectory established earlier in Southern Europe, Latin America and a few countries in Asia. Centrist political parties with convergent and moderate programs dominated most elections. Parties opposing capitalism and/or democracy barely existed and, if so, were confined to the fringes of political life. The European Union had completed its 'Internal Market' and just made a 'Great Leap Forward' with the creation of a common currency. Regional organizations were spouting up all over the globe, lowering barriers to trade and investment. All of this seemed to promise further economic growth, less inflation, full employment, more and better well-being - undisturbed by political threats.

The conjuncture of these events presaged a peaceful and prosperous evolution for the foreseeable future, especially in social progress. National states were expected to be much less pre-occupied with external or internal security. The bounty from the presumed decline in military and police expenditures was supposed to be diverted to new or improved welfare and educational policies. Poverty would be eliminated; public health would improve; education levels would rise; pensions would become more bountiful; inequalities in personal and regional income would diminish; access to and fairness within the judicial system would be assured. Thanks to this convergence of 'all good things,' the legitimacy of public institutions would be guaranteed and the grateful citizens would come to support and trust the politicians that would be associated with the production of such manifestly superior public goods.

It would not be an exaggeration to observe that virtually all of these expectations were frustrated. The 'Dog of Social Progress' did not bark in the 1980s and has remained silent into 
the $21^{\text {st }}$ Century. This reversal of expectations has led to widespread disillusion and distrust with both the new and old liberal democracies and mistrust of the politicians that make them work. Traditional political parties lost members; voters no longer identified with them; fringe parties increased their presence in elections and in the public debate. The judicial process has achieved more attention than before, if only because of persistent stalemates in the political process, and issues involving access to courts and the fairness of their decisions increased. The institutions and performance of capitalism are under greater criticism than any time since the 1930s. Instead of the expected progress in social conditions, citizens and denizens in countries across the globe have suffered from decreases in policy entitlements and in public spending on programs designed to combat poverty, ill health, poor education and income inequality - with the result that virtually all indicators of social distress have risen since the 1990s.

Why did this happen? What intervened during this period to so dramatically frustrate expectations? And why has it persisted into the following century?

No doubt economic factors played an important role. Growth rates declined and remained low in the developed countries; they increased but became more erratic in the developing ones. Where the aggregate demand of consumers declined, so did the incentives for investment and the margins of profitability. This, in turn, reduced public revenues and augmented resistance to redistributive policies - at the same time that the need for insuring against social risks and for compensating in response to market failures became more acute. One response of both private persons and state authorities was to borrow more funds in an effort to fill the widening gap - and that subsequently generated a massive crisis in currency markets, credit institutions, fiscal policies and public confidence. If all that were not enough, the very core of capitalist accumulation shifted from industry to services and within the service sector, to financial services. Much of the reduced growth was gained through 
speculation by firms that employed few people and rewarded them generously - at the expense of the general public. Inequalities in income and wealth climbed to levels not experienced since the end of the $19^{\text {th }}$ Century - before the policy foundations for improved social progress were laid.

Changes in political conditions were quick to follow and even more disruptive of the trend toward social progress. Centrist and especially Leftist parties - historically the main supporters of increases in citizen entitlements - lost members and vote share. They have been increasingly replaced by populist fringe parties and candidacies that promise to address the decline in well-being, but have no concrete proposals for accomplishing this. At the same time, fewer and fewer citizens identify with any party and more and more of them bother to vote at all. Labour unions and employer associations became less representative of their respective class interests, and previously stable patterns of collective bargaining between them have dissolved into purely individual or plant level agreements. Those segments of the working class that are unemployed or precariously employed and, hence, no longer covered by collective agreements or eligible for public entitlements have become increasingly alienated from the political process altogether and more likely to respond to populist and national appeals.

As significant as they may be, these economic factors and political conditions might have been insufficient to explain the reversal in trend were it not for an even more important change in the nature of the unit responsible for deciding on the public policies that affect social progress. That unit is (or, better, was) the sovereign national state. It was presumed that it alone had the capacity to impose regulations, redistribute benefits, subsidize production, promote education and to do so by exercising its legitimate and exclusive authority over a distinct territory. Beginning in the 1980s, its capacity to do all of this in a sovereign manner has declined. A combination of transformations - conveniently summarized by the concept of 
globalization - has emerged that limit the extent to which any state take these policies without reference to public and/or private actors outside its territory and beyond its jurisdiction. Whether these constraints are imposed by supra-national institutions at the global or regional level is less important than the extent to which they must be respected and the consequences that will follow if they are not. Putting the matter bluntly, social progress is no longer the exclusive product of national states.

In retrospect, it has become apparent that the increase in social progress that followed the Second World War was the product of an unusual coincidence of economic factors and political conditions. There was a shortage of labor for physical reconstruction, a manifest need for investment, and enormous opportunities to satisfy pent-up consumer demand (and to make assured profits). Moreover, governments had made extensive promises to disfavoured groups during the war in order to ensure their loyalty and their willingness to make sacrifices. National states had won the war and exercised uncontested authority over their respective territories (with the exception of those who lost the war and were occupied by the victors). If this were not enough, there was also the persistent menace of the Soviet Union and national communist parties to justify making concessions to less favoured groups. This constellation of factors and conditions was anchored in a relative balance between competing classes and converging ideologies that persisted for some forty years or so. It has been labelled 'the postwar settlement' and it contributed very substantially to the expansion of welfare and educational policies during this period. While it was particularly characteristic of post-war Europe and North America, it set precedents and produced policy innovations that affected public decision-makers and private interest representative in other parts of the world.

'Social progress depends upon social contract,' that is the lesson to be gleaned from the post-war history of the North and West and from the post-colonial history of the South and East. Needless to say, the socio-economic content of that contract and the political 
process that produces it has varied a great deal - as has its durability. Everywhere that it has existed, it has rested on two generic features: (1) the self-organization of the conflicting class interests at stake; and (2) the relative balance of power between them - as well as on the competing presence of other cleavages that cut across the functional conflict between capital and labor and serve to divide or weaken their respective capacities to act collectively, as well as to complicate the process of ideological justification. In pre-capitalist economies and traditional societies, both the interests at stake and the balance of power between them will be significantly different. A viable and effective social contract will depend more upon cultural norms of responsibility and reciprocity, rather than calculations of material advantage. But once capitalism has penetrated the society and undermined traditional groups and norms, social progress will depend primarily upon arriving at a compromise between capital and labor. This will, no doubt, be made more difficult by the persistence of tribal, religious, linguistic, generational, gender and centre-periphery conflicts in any specific case, but the core remains a mutually consensual agreement on how the economic surplus is to be distributed and the production of wealth is to be regulated - and by whom for the benefit of whom. Needless to say, such contracts are not always likely to be self-enforcing, hence, the need for the intervention of public authority to ensure that the contract will be observed. Without a state to monitor behaviour, redistribute benefits, regulate production, implement policies without discrimination and sanction non-compliance, all social contracts would be vulnerable to 'opportunistic' defections in response to momentary advantage. In other words, regardless of the type of regime (although democracies are far more reliable in this regard than autocracies), their viability and longevity depends, not just on the perceived fairness of their distributive impact, but also on the existence of an established and reliable legal system to adjudicate eventual conflicts and compensate victims. Without the rule of law in the 
background to enforce them, no social contract is likely to persist for long - and, hence, no social progress is likely to emerge or to be sustained.

In the advanced capitalist economies and established democratic polities of Western Europe and North America, considerable social progress was achieved during the forty or so years after the end of the Second World War. This was accomplished, however, as the result of two quite different processes of social contracting. The first favourable scenario has been called pluralist; the second corporatist.

In the former, characteristic of polities dominated by Conservative or Liberal political parties, the contract was 'unsigned.' It emerged spontaneously from the exchanges, largely among individuals and firms, in product and labor markets. By combining supply and demand in a competitive manner, they would create a 'fair' and 'consensual' distribution of benefits provided that these markets were neither monopolistic nor oligopolistic and provided that public authority was licensed to ensure that contracts were obeyed, that regulations were followed and that weak and marginalized citizens were compensated. Social justice (or progress) depended primarily upon the efforts of individuals to realise their potential according to their competitive advantage in contributing to growth in the general economy. Failure to do so was a matter of personal responsibility, not a failure of the system as a whole. In accordance with liberal principles, short-comings in this distributive process would (and should) be cared for by the voluntary actions of 'charitable' organizations in civil society, not by governments. The fact that labour was then relatively scarce and had a momentarily greater capacity for collective action that could plausibly affect the profitability of firms provided a relative balance in class forces that encouraged moderation and compromise. The ideological hegemony of liberalism in these polities ensured that the 'freedom' to compete for goods and services was regarded as preferable to the 'tyranny' of state intervention - and the Soviet Union was there to demonstrate what that would mean. 
In the latter, characteristic of polities dominated by Social Democratic or Christian Democratic parties, the contract was 'signed.' It emerged as the result of explicit bargaining between organizations representing conflicting class interests and capable of ensuring the compliance of their respective members. Supply and demand were monitored and controlled by both public and semi-public institutions, as was the distribution (and, in some case, redistribution) of eventual benefits by ensuring that wages more or less tracked the evolution of productivity and that working conditions and skill levels would continuously improve. Critical for the success of such an allocation process was the high level of self-organization of the contracting parties. Not only were a large proportion of the respective social classes incorporated (whether voluntarily or involuntarily) into the institutions that represented their interests, but these organizations were comprehensive and hierarchically ordered with regard to the classes and sectors they represented, monopolistic in that they faced no competition from other organizations, and officially recognized by the state and granted assured access to decision-making and a role in implementing the policies eventually taken. The ideological justification for such arrangements was weaker than that provided by the 'freedom' of liberalism. They were legitimated more by their success in increasing well-being than by their conformity to existing doctrine.

Signed or unsigned, the social contract no longer provides a reliable basis for social progress - and has not been doing so since, roughly, the early 1980s. The two elements that combined to produce it - the self-organization of conflicting class interests and the relative balance of power between them - have changed beyond recognition. Associations representing capital, labor and the profession have lost members and the capacity to act collectively and credibly - as have the so-called 'sister political parties' that supported them in the electoral and legislative process. Due to the globalization of capitalism and the shift of its center of accumulation to finance from industry, the reciprocal capacity of labor and 
capital to influence each other's behaviour and, thereby, compel them to resort to compromises in the distribution of their joint product has literally disappeared in the favour of the latter. In the absence of these two elements, it is difficult to imagine any significant increase in social progress for the foreseeable future, at least in those Northern and Western countries that had previously played a leading role in its advent. Hopefully, there may exist more favourable conditions for it in some of the countries of the South and East that are more protected from globalization and whose capitalism is still more industrial.

\section{References}

Abdolian, L. F., Takooshian, H. 2002. 'The USA Patriot Act: Civil Liberties, the Media, and Public Opinion’, Fordham Urban Law Journal 30(4): 1429-1453.

Agamben, G. 2005. State of Exception, University of Chicago Press.

Agamben, G., Raulff, U. 2004. 'Interview with Giorgio Agamben-Life, A work of art without an author: The state of exception, the administration of disorder and private life'. Interviewed by U. Raulff, German Law Journal, at http://www. germanlawjournal. com/article. php.

Alesina, A., Spolaore, E. 2003. The Size of Nations, MIT Press.

Amin, A. 1999. 'An Institutionalist Perspective on Regional Economic Development', International Journal of Urban and Regional Research, 23(2): 365-78.

Arendt, H.. 1958. The Human Condition. University of Chicago Press.

Badie, B. 1995. La fin des territoires. Essai sur le désordre international et sur l'utilité sociale du respect, Paris: Fayard.

Baiocchi, G. 2005. Militants and citizens: the politics of participatory democracy in Porto Alegre, Stanford University Press. 
Baiocchi, G., Ganuza, E. 2012. 'No parties, No Banners. The Spanish Experiment with Direct Democracy' in Boston Review, January.

Baiocchi, G., Ganuza, E. 2016. Popular Democracy and the Paradoxes of Participation, Stanford University Press.

Baiocchi, G., Heller, P., Silva, M. 2011. Bootstrapping Democracy: Transforming Local Governance and Civil Socity in Brazil, Stanford University Press.

Bakardjieva, M. (2005). Internet society: The Internet in everyday life. Sage.

Baogang, H., Galligan, B. and Inoguchi, T. (eds.) 2007. Federalism in Asia, Cheltenham: Edward Elgar.

Barber, B.R. The New Telecommunications Technology: Endless Frontier or the End of Democracy? In A Communications Cornucopia: Markle Foundation Essays on Information Policy; Noll, R.G., Price, M.E. Eds.; Brookings Institution Press: Washington D.C., 1998; 312-333.

Bartolini, S. 2005. Restructuring Europe. Centre Formation, System Building, and Political Structuring between the Nation State and the European Union, Oxford University Press.

Bartolini, S., Mair, P. 1990. Identity, Competition, and Electoral Availability: The Stabilization of European Electorates 1885-1985, Cambridge University Press.

Bauman, Z. 1997. Liquid Modernity. Polity Press.

Beck, U. 1999. World Risk Society, Polity Press.

Beck, U. 1992. Risk Society: Towards a New Modernity. Sage Publications.

Benhabib, S. 2005. 'Borders, Boundaries, and Citizenship', PSOnline, October, 673-677.

Benkler, Y. (2006). The Wealth of Networks: How Social Production Transforms Markets and Freedom. Yale University Press. 
Berman, B., Eyoh, D. and Kymlicka, W. (eds.) 2004. Ethnicity and Democracy in Africa, Ohio University Press.

Bertrand, J., Laliberté, A. (eds.) 2010. Multination States in Asia: Accommodation of Resistance?, Cambridge University Press.

Bingham, Lisa Blomgren, Tina Nabatchi, and Rosemary O'Leary. 'The new governance: Practices and processes for stakeholder and citizen participation in the work of government.' Public administration review 65, no. 5 (2005): 547-558.

Bohle, D., Greskovits, B. 2013. Capitalist Diversity on Europe's Periphery, Cornell University Press.

Bork, R. H. 1993 (1978). The Antitrust Paradox: A Policy at War with Itself, New York: Free Press.

Bristow, G. 2010. Critical Reflections on Regional Competitiveness, London: Routledge.

Brown, W. 2015. Undoing The Demos: Neoliberalism's Stealth Revolution, MIT Press.

Butler, J. 2009. 'Performativity, precarity and sexual politics', AIBR. Revista de Antropología Iberoamericana, 4(3): i-xiii.

Camic, Charles, Neil Gross, and Michèle Lamont, eds. 2011. Social Knowledge in the Making. University of Chicago Press.

Caramani, D. 2004. The Nationalization of Politics. The Formation of National Electorates and Party Systems in Western Europe, Cambridge University Press.

Castells, M. (2015). Networks of Outrage and Hope: Social Movements in the Internet Age. John Wiley \& Sons.

Catt, H., Murphy, M. 2002. Sub-State Nationalism: A Comparative Analysis of Institutional Design, Routledge.

Cavatorta, F. 2012. 'Arab Spring: the awakening of civil society. A general overview', European Institute of the Mediterranean Yearbook, 75-81. 
Cichowski, R., Stone, A. 2003. 'Participation, representative democracy and the courts', in B.E. Cain et al. (ed.), Democracy transformed ? Expanded political opportunities in advanced industrial democracies, Oxford University Press, 192-202.Chilvers, J. and M. Kearnes. 2015. Remaking Participation : Science, Environment and Emergent Publics. Taylor and Francis.

Cleaver, F. 1999. 'Paradoxes of participation: questioning participatory approaches to development', Journal of international development, 11(4): 597-612.

Cole, D. 2003. Enemy Aliens: Double Standards and Constitutional Freedoms in the War on Terror, New York: The New Press.

Coleman (2011) Anonymous: From the Lulz to Collective Action. In Politics in the Age of Secrecy and Transparency, edited by Gabriella Colleman. http://mediacommons.futureofthebook.org/tne/pieces/anonymous-lulz-collectiveaction.

Connelly, J. 2007. 'The relative universality of human rights', Human Rights Quarterly, 29, 281-306.

Connelly, J. 2008. 'Human Rights: Both universal and relative (a reply to Michael Goodhart)', Human Rights Quarterly, 30, 194-204.

Cooke, B., Kothari, U. (eds.) 2001. Participation: The new tyranny?, London: Zed Books.Corburn, J.. 2005. Street Science: Community Knowledge and Environmental Health Justice. MIT Press.

Cornell, S., Hartmann, D. 2007. Ethnicity and race: making identities in a changing world, Pine Forge Press.

Crouch, C. 2004. Post-democracy, Polity Press. 
Crouch, C. 2015. 'Can there be a normative theory of corporate political power?', in V. Schneider and B. Eberlein (eds.) Complex Democracy: Varieties, Crises, and Transformations, Springer.

Crouch, C. 2016. Society and Social Change in 21st Century Europe, Palgrave Macmillan.

Crouch, C., Le Galès, P., Trigilia, C., Voelzkow, H. 2001. Local Production Systems in Europe. Rise or Demise?, Oxford University Press.

Dahl, R.A. 1961. Who Governs?: Democracy and Power in an American City, New Haven CT: Yale University Press.

Dahl, R.A. 1971. Polyarchy, Participation and Opposition, Yale University Press.

Dahl, R.A. 1982. Dilemmas of Pluralist Democracy: Autonomy Versus Control, Yale University Press.

Dahlberg, Lincoln. 2001. 'The Internet and Democratic Discourse.' Information, Communication \& Society 4 (4):615-633.

Dalton, R. J., Wattenberg, M.P. (eds.) 2000. Parties without Partisans: Political Change in Advanced Industrial Democracies, Oxford University Press.

della Porta, D. 2015. Social Movements in Times of Austerity, Polity Press.

della Porta, D. (ed.) 2017. Riding the Wave, Amsterdam University Press.

della Porta, D. 2013. Can Democracy be Saved?. Polity Press.

della Porta, D. et al. 2017. Late neoliberalism and its Discontent. Palgrave.

della Porta, D., Fernandez, J., Kouki, H., Mosca, L. 2017 (eds.) Forthcoming. Movement Parties in Times of (Anti)austerity, Polity Press.

Deutsch, K.W. 1972. Nationalism and social communication: an inquiry into the foundations of nationality, MIT Press.

Dewey, J. 1927. The Public and Its Problems. Holt. 
Dezalay, Y., Garth, B. 1996. Dealing in Virtue. International Commercial Arbitration and the Construction of a Transnational Legal Order, University of Chicago Press.

Diamond, L. J. 1990. 'Three paradoxes of democracy', Journal of Democracy, 1(3): 48-60.

Douzinas, C. 2000. The End of Human Rights, Hart Publishing.

Douzinas, C. 2007. Human Rights and Empire: The Political Philosophy of Cosmopolitanism, Routledge.

Durkheim, E. 1964. The Division of Labour in Society, New York: Free Press.

Dutton, W.H., \& Peltu, M. (2007). Reconfiguring Government-Public Engagements: Enhancing the Communicative Power of Citizens.

Eddy, E.C. 2005. 'Privatizing the Patriot Act: The Criminalization of Environmental and Animal Protectionists as Terrorists', Pace Environmental Law Review, 22(2): 261327.

Ericson, R.V. 1994. 'The Royal Commission on Criminal Justice System Surveillance', in M. McConville and L. Bridges (eds.) Criminal Justice in Crisis, Aldershot, UK: Edward Elgar, 113-140.

Ezrahi, Y. 1990. The Descent of Icarus: Science and the Transformation of Contemporary Democracy. Cambridge, MA: Harvard University Press.

Felt, Ulrike, Clark Miller, Laurel Smith-Doerr, and Rayvon Fouché, eds.. 2016. Handbook of Science and Technology Studies. Cambridge, MA: MIT Press.

Ferguson, J. 1990. The anti-politics machine: development, depoliticization, and bureaucratic power in Lesotho, Cambridge University Press.

Ferguson, Y.H. \& Mansbach, R.W. (1996), Polities: Authority, Identities, and Change, Columbia: University of South Carolina Press.

Ferrara, A. 2003. 'Two notions of humanity and the judgement argument for human rights', Political Theory, 31(3): 392-420. 
Fincham, K. 2013. 'Shifting youth identities and notions of citizenship in the Palestinian Diaspora: the case of Lebanon', in D. Kiwan (ed.) Naturalization policies, education and citizenship: multicultural and multination societies in international perspective, Palgrave Macmillan.

Finer, S.E. 1997. The History of Government, III. Empires, Monarchies and the Modern State, Oxford University Press.

Fleck, L.. 1979 [1935]. Genesis and Development of a Scientific Fact (trans. Thaddeus J. Trenn). University Chicago Press.

Flood, J. 1996. 'Megalawyering in the global order: The cultural, social and economic transformation of global legal practice', International Journal of the Legal Profession, $3,169-213$.

Flora, P., Kuhnle, S., Urwin, D., (eds.) 1999. State Formation, Nation-Building and Mass Politics in Europe. The Theory of Stein Rokkan, Oxford University Press.

Font, J., della Porta, D., and Sintomer, Y. 2014. 'Participatory democracy in Southern Europe: causes, characteristics and consequences', Rowman and Littlefield, London.

Foucault, M. 1977. Discipline and Punishment: The Birth of the Prison (trans. Alan Sheridan). Vintage Books.

Foucault, M.. 1980. Power/Knowledge: Selected Interviews and Other Writings, 1972-1977 (trans. Colin Gordon et al.). New York: Pantheon.

Froomkin, A. Michael. 2004. 'Technologies for Democracy.' In Democracy Online: The Prospects for Democratic Renewal Through the Internet, edited by P. Shane. London: Routledge.

Fung, A. 2015. 'Putting The Public Back Into Governance: The Challenges Of Citizen Participation And Its Future', Public Administration Review, 75(4): 513-522. 
Ganuza, E., Nez, H., Morales, E. 2014. 'The Struggle for a Voice: Tensions between Associations and Citizens in Participatory Budgeting', International Journal of Urban and Regional Research, 2274-2291.

Ghai, Y. (ed.) 2000. Autonomy and Ethnicity: Negotiating Competing Claims in Multi-ethnic States, Cambridge University Press.

Ghai, Y. and Woodman, S. (eds.) 2013. Practicing Self-Government: A Comparative Study of Autonomous Regions, Cambridge University Press.

Gibbons, Michael, Camille Limoges, Helga Nowotny, Simon Schwartzman, Peter Scott, and Martin Trow. 1994. The New Production of Knowledge. London: Sage Publications.

Giddens, A. 1985. The Nation State and Violence, Polity Press.

Gilens, M. 2012. Affluence and Influence: Economic Inequality and Political Power in America, Princeton University Press.

Gladwell, M. (2010). Small change. The New Yorker, 4(2010), 42-49.

Glendon, M.A. 1991. Rigths Talk. The Impoverishment of Political Discourse, New York, Free Press.

Godwin, M.L. 2014. 'Civic Engagement And Fiscal Stress In American Cities : Insights From The Great Recession', 46(4), 249-259.

Goode, L. (2009). Social news, citizen journalism and democracy. New Media \& Society.

Goodhart, M. 2008. 'Neither relative nor universal: a response to Donnelly', Human Rights Quarterly, 30(1): 183-193.

Gott, G. 2002. 'Imperial Humanitarianism: History of an Arrested Dialectic', Moral Imperialism: A Critical Anthology, 19.

Gottfried, J., \& Shearer, E. (2016). News use across social media platforms 2016. Pew Research Center. 
Haas, P.M. 1990. Saving the Mediterranean: The Politics of International Environmental Cooperation. New York: Columbia University Press.

Habermas, J. (1996) Between Facts and Norms: Contribution to a Discursive Theory of Law and Democracy, Cambridge: MIT Press.

Habermas, J. 1970. Toward a Rational Society: Student Protest, Science, and Politics. Boston: Beacon.

Hanafi, S. 2012. 'The Arab revolutions: the emergence of a new political subjectivity', Contemporary Arab Affairs, 5(2): 198-213.Hardt, M. and Negri, A. 2000. Empire. Harvard University Press.

Held, D. 1993. Political Theory and the Modern State, Polity Press.

Heller, P. 2001. 'Moving the State: The Politics of Democratic Decentralization in Kerala, South Africa, and Porto Alegre', Politics and Society 29(1): 131-163.

Hicken, A., Kuhonta, E.M. (eds.) 2015. Party System Institutionalization in Asia: Democracies, Autocracies, and the Shadows of the Past, Cambridge University Press.

Hickey, S., Mohan, G. (eds.) 2004. Participation--from tyranny to transformation? Exploring new approaches to participation in development, London: Zed Books.

Hindman, M. (2008). The myth of digital democracy. Princeton University Press.

Hirschl, R. 2004. Towards Juristocracy: The Origins and Consequences of the New Constitutionalism, Harvard University Press.

Hurlbut, J.B.. Forthcoming. Experiments in Democracy: Human Embryo Research and the Politics of Public Bioethics. Columbia University Press.

Isin, E. F. 2008. 'Theorizing acts of citizenship' in E.F. Isin and G.M. Nielsen (eds.) Acts of Citizenship, London: Zed Books, 15-43.

Isin, E. F. 2009. 'Citizenship in flux: The figure of the activist citizen', Subjectivity, 29: 367388. 
Jasanoff, S., ed. 2004. States of Knowledge: The Co-Production of Science and Social Order. London: Routledge.

Jasanoff, S. 1990. The Fifth Branch: Science Advisers as Policymakers. Harvard University Press.

Jasanoff, S. 2005. Designs on Nature: Science and Democracy in Europe and the United States. Princeton, NJ: Princeton University Press.

Jones, S. (Ed.). (1998). Cybersociety 2.0: Revisiting computer-mediated community and technology (Vol. 2). Sage Publications.

Joppke, C. 2010. 'The inevitable lightening of citizenship', European Journal of Sociology, 51(1): 9-32.

Kantor, P. 1995. The Dependent City Revisited. The Changing Political Economy of Urban Development and Social Policy, Boulder: Glenview.

Katz, R.S., Mair, P. 1995. 'Changing Models of Party Organization and Party Democracy: The Emergence of the Cartel Party', Party Politics 1(1): 5-31.

Kauppi N., Madsen M.R. (eds.) 2012. Transnational Power Elites: The New Professionals of Governance, Law and Security, Routledge.

Keating, M. 2001. Plurinational Democracy: Stateless Nations in a Post-Sovereignty Era, Oxford University Press.

Keating, M. 2013. Rescaling the European State. The making of territory and the rise of the meso, Oxford University Press.

Keating, M., Wilson, A. 2014. 'Regions with regionalism? The rescaling of interest groups in six European States', European Journal of Political Research, 53(4): 840-57.

Kelemen, D. 2011. The Rise of Eurolegalism. The Transformation of Law and Governance in Europe, Harvard University Press. 
Kelly Garrett, R. (2006). Protest in an information society: A review of literature on social movements and new ICTs. Information, communication \& society, 9(02), 202-224.

Kitschelt, H., Wilkinson S.I., (eds.) 2007. Patrons, Clients, and Policies: Patterns of Democratic Accountability and Political Competition, Cambridge University Press.

Kiwan, D. 2008. Education for Inclusive Citizenship, Routledge.

Kiwan, D. 2010. 'Highly skilled guest-workers in the UK', Policy and Society, 29(4): 333343.

Kiwan, D. 2013. 'Introduction', in D. Kiwan (ed.) Naturalization policies, education and citizenship: multicultural and multination societies in international perspective, Palgrave Macmillan.

Kiwan, D. 2014. 'Emerging Forms of Citizenship in the Arab World' in Isin, E., Nyers, P. (eds.) Routledge Global Handbook of Citizenship Studies, Routledge.

Kiwan, D. 2016a, in press. 'Syrian and Syrian Palestinian women in Lebanon: 'actors of citizenship'?', in M. Shalaby and V. Moghadam (eds.), Empowering Women after the Arab Spring, Palgrave Macmillan.

Kiwan, D. 2016b, in press. 'Race, Ethnicity and citizenship in education: locating intersectionality and migration for social justice' in A. Peterson, R. Hattam, M. Zembylas, and J. Arthur (eds.) The Palgrave International Handbook of Education for Citizenship and Social Justice, Palgrave Macmillan.

Kocka, J. 2014. Geschichte des Kapitalismus. Munich: C.H. Beck Verlag.

Kriesi, H. 2008. 'Contexts of Party Mobilization,' in H. Kriesi, E. Grande, R. Lachat, M. Dolezal, S. Bornschier, T. Frey, West European Politics in the Age of Globalization, Cambridge University Press, 23-52.

Krugman, P. (2011) 'The New Economic Geography, Now Middle Aged', Regional Studies, 45(1): 1-7. 
Kuhn, T.. 1962. The Structure of Scientific Revolutions. University of Chicago Press.

Kymlicka, W. 1995. Multicultural Citizenship: A liberal theory of minority rights, Oxford University Press.

Kymlicka, W. 2001. 'Immigrant Integration and Minority Nationalism' in M. Keating and J. McGarry (eds.) Minority Nationalism and the Changing International Order, Oxford University Press.

Kymlicka, W., Pfostl, E. 2014. 'Introduction' in W. Kymlicka and E. Pfostl, (eds.), Multiculturalism and Minority Rights in the Arab World, Oxford University Press.Laclau, E. 2005. On Populist Reason. Verso.

Latour, B. 1987. Science in Action: How to Follow Scientists and Engineers through Society. Cambridge, MA: Harvard University Press.

Leal, P. 2007 'Participation: the ascendancy of a buzword in the neo-liberal era', Development in practice, 17(4-5): 539-548.

Lee, C. W., Mcquarrie, M., Walker, E.T. 2015. Democratizing Inequalities: Dilemmas of the New Public Participation, New York University Press.

Lee, C.W. 2015. Do-It-Yourself. Democracy: The Rise Of The Public Engagement Industry, Oxford University Press.

Leighninger, M. 2006. The next form of democracy: How expert rule is giving way to shared governance--and why politics will never be the same, Vanderbilt University Press.

Lentsch, J. and P. Weingart. 2011. The Politics of Scientific Advice: Institutional Design for Quality Assurance. Cambridge University Press.

Levi-Faur, D. 2011. The Odyssey of the Regulatory State. The Rescue of the Welfare State, Jerusalem Papers in Regulation and Governance, Working paper $\mathrm{n}^{\circ} 39$.

Li, T. M. 2005. 'Beyond 'the state' and failed schemes', American anthropologist, 107(3): 383-394. 
Lindblom, C. E. 1977. Politics and Markets, New York: Basic Books.

Lipset, S.M., Rokkan, S. 1967. 'Cleavage Structures, Party Systems and Voter Alignments' in S.M. Lipset and S. Rokkan Party Systems and Voter Alignments, New York: Free Press, 1-64.

Loader, I. 2000. 'Plural Policing and Democratic Governance', Social and Legal Studies, 9(3): 323-345.

Loader, I., Walker, N. 2007. Civilizing Security, Cambridge University Press.

Loughlin, M. 1992. Public Law and Political Theory, Oxford University Press.

Lupu, N. 2016. Party Brands in Crisis: Partisanship, Brand Dilution, and the Breakdown of Political Parties in Latin America, Cambridge University Press.

Madrid, R. L. 2012. The Rise of Ethnic Politics in Latin America, Cambridge University Press.

Madsen, M. 2008. La genèse de l'Europe des droits de l'homme. Enjeux juridiques et strategies d'Etat (France, Royaume Uni, Scandinavie), Presses de l'Université de Strasbourg.

Maduro, M., Vauchez, A. (eds.). 2012. Courts, Social Change and Judicial Independence, Working paper, Global Governance Programme, European University Institute.

Mainwaring, S., Zoco, E. 2007. 'Political Sequences and the Stabilization of Interparty Competition: Electoral Volatility in Old and New Democracies', Party Politics, 13(2): $155-178$.

Mair, P. 2013. Ruling the Void: The Hollowing of Western Democracy, Verso.

Mann, M. 1993. The Sources of Social Power, volume II. The rise of classes and nationstates, 1760-1914, Cambridge University Press.

Mansuri, G. and Vijayendra, R. 2013. Localizing Development: Does Participation Work? Washington, D.C.: World Bank. 
Marshall, A. 1920. Principles of Economics, Palgrave Macmillan.

Marshall, T. H. 1992. Citizenship and social class, London: Pluto.

McAdam, D., Tarrow, S., Tilly, C. 2001. Dynamics of Contention, Cambridge University Press.

Merkel, W. 2014. 'Is capitalism compatible with democracy?', Zeitschrift für Vergleichende Politikwissenschaft, 8(2): 109-128.

Mill, J.S. 1972. Utilitarianism, On Liberty and Considerations on Representative Government, London: Dent.

Miller, D. 2002. 'Group rights, human rights and citizenship', European Journal of Philosophy, 10(2): 178-195.

Mohan, G. 2001. 'Beyond Participation: Strategies for Deeper Sovereignty' in Cooke, B. and Kothari, U. (eds.) Participation: The New Tyranny, London: Zed Press, 153-167.

Morgan, J. 2011. Bankrupt Representation and Party System Collapse, University of Pennsylvania Press.

Morozov, Evgeny. 2009. The Brave New World of Slacktivism. http://neteffect.foreignpolicy.com/posts/2009/05/19/the_brave_new_world_of_slackti vism

Moyn, S. 2010. The Last Utopia. Human Rights in History, Harvard University Press.

Müller Jan-Werner (2016), What Is Populism?, University of Pennsylvania Press.

Nash, C. 2009. 'Between citizenship and human rights', Sociology, 43(6): 1067-1083.

Nyers, P. 2010. 'No-one is illegal: between city and nation', Studies in Social Justice, 4(2): 127-143.

OECD. 2011. Divided We Stand:Why Inequality Keeps Rising, OECD Publishing.

Ohmae, K. 1995. The End of the Nation State: The Rise of Regional Economies, New York: The Free Press. 
Olson, M. 1965. The Theory of Collective Action, Yale University Press.

Pacquet, M. 2012. 'Beyond appearance: citizenship tests in Canada and the UK', International Migration and Integration, 13, 243-260.

Peck, J., Theodore, N. 2010. 'Mobilizing policy: Models, methods, and mutations', Geoforum 41(2):169-174.

Peterson, A. 2012. 'Legitimacy and the Swedish Security Service's Attempts to Mobilize Muslim Communities', International Journal of Criminology and Sociology, 1(1): 112.

Peterson, A. 2016. 'The Institutionalization Processes of a Neo-Nazi Movement PartySecuring Social Movement Outcomes', in L. Bosi, K. Uba, M. Guigni (eds.) The Consequences of Social Movements: People, Policies and Institutions, Cambridge University Press, 314-337.

Peterson, A., Wahlström, M. 2015. 'Repression: The Governance of Domestic Dissent', in D. della Porta and M. Diani (eds.) Oxford Handbook of Social Movements, Oxford University Press.

Peterson, P. 1985. City Limits, University of Chicago Press.

Piketty, T. 2013. Le capital au 21e siècle. Paris: Éditions du Seuil.

Pizzorno, A. 1998. Il potere dei giudici. Stato democratico e controllo della virtu, Laterza, Bari.

Pollitt, C., Bouckaert, G. 2011. Public Management Reform. A Comparative Analysis: New Public Management, Governance and the Neo-Weberian State, Oxford University Press.

Porter, M. 2001. 'Regions and the new Economics of Competition', in A.J. Scott (ed.) Global City Regions. Trends, Theory, Policy, Oxford University Press.

Posner, R. A. 2001. Antitrust Law, University of Chicago Press. 
Putnam, R. 1993. Making Democracy Work. Civic Traditions in Modern Italy, Princeton University Press.

Raco, M. 2003. 'Governmentality, subject-building, and the discourses and practices of devolution in the UK', Transactions of the Institute of British Geographers. 28, 75-95.

Rae, H. 2002. State Identities and the Homogenization of Peoples, Cambridge University Press.

Rao, Vijayendra, and Paromita Sanyal. 'Dignity through discourse: poverty and the culture of deliberation in Indian village democracies.' The Annals of the American Academy of Political and Social Science 629.1 (2010): 146-172.

Riedl, R.B. 2014. Authoritarian Origins of Democratic Party Systems in Africa, Cambridge University Press.

Roberts, K. M. 2014. Changing Course in Latin America: Party Systems in the Neoliberal Era, Cambridge University Press.

Rokkan, S. 1999. State Formation, Nation-Building and Mass Politics in Europe. The Theory of Stein Rokkan edited by Peter Flora, Stein Kuhnle and Derek Urwin, Oxford: Oxford University Press.

Root, A. 2007. Market Citizenship: experiments in democracy and globalization, Sage Publications.

Rupnik, J. 2012. 'How things went wrong', Journal of Democracy, 23(3): 132-137.

Sassen, S. 2000. World Cities in a Global Economy, 2nd edition, Thousand Oaks: Sage.

Sassen, S. 2008. Territory, Authority, Rights. From Medieval to Global Assemblages, updated edition, Princeton: Princeton University Press.

Schattschneider, E. E. 1942. Party Government, New York: Rinehart. 
Schmitter, P. C. 2001. 'Parties Are Not What They Once Were', in L. Diamond and R. Gunther (eds.) Political Parties and Democracy, Johns Hopkins University Press, 6789.

Scott, A. 1998. Regions and the World Economy. The Coming Shape of Global Production, Competition, and Political Order, Oxford University Press.

Scott, A., Agnew J., Soja E. and Storper M. 2001. 'Global City-Regions', in Scott A. (ed.), Global City-Regions. Trends, Theory, Policy, Oxford: Oxford University Press.

Shachar, A., Hirschl, R. 2014. 'On Citizenship, States and Markets', The Journal of Political Philosophy, 22(2): 231-257.

Shafir, G. 1998. 'Introduction' in G. Shafir (ed.) The Citizenship Debates, Minnesota University Press, 1-28.

Sikkink, K. 2011. The Justice Cascade: How Human Rights Prosecutions Are Changing the World. Norton.

Silva, E. 2009. Challenging Neoliberalism in Latin America, Cambridge University Press.

Skouteris, T. 2006. 'The New Tribunalism: Strategies of (De)Legitimzation in the Era of Adjudication', Finnish Yearbook of International Law, 17, 307-57.

Skowronek, S., S.M. Engel and B. Ackerman, eds. 2016. The Progressives' Century: Political Reform, Constitutional Government, and the Modern American State. Yale University Press.

Skowronek, S., S.M. Engel and B. Ackerman, eds. 2016. The Progressives' Century: Political Reform, Constitutional Government, and the Modern American State. Yale University Press.

Skowronek, S., S.M. Engel and B. Ackerman, eds. 2016. The Progressives' Century: Political Reform, Constitutional Government, and the Modern American State. Yale University Press. 
Smith, A.D. 1983. State and Nation in the Third World, London: Wheatsheaf.

Smith, A.D. 1998. Nationalism and Modernism: A Critical Survey of Recent Theories of Nations and Nationalism, Routledge.

Soysal, Y. 1994. Limits of Citizenship: Migrants and Postnational membership in Europe, University of Chicago Press.Standing, G. 2011. The Precariat: the New Dangerous Class. Bloomsbury Academic.

Stojanović, N. 2010. 'Mononational and Multinational States: A Valid Dichotomy?', paper for conference on Legal Reasoning and European Law: The Perspective of Neil MacCormick, European University Institute, $21^{\text {st }}$ May 2010.

Stokes, S. C., Dunning, T., Nazareno, M., Brusco, V. 2013. Brokers, Voters, and Clientelism: The Puzle of Distributive Politics, Cambridge University Press.

Stone, A., Brunell, T. 2013. 'Trustee Courts and the Judicialization of International Regimes: The Politics of Majoritarian Activism in the ECHR, the EU, and the WTO', Journal of Law and Courts, 1(1): 61-88.

Streck, John M. 1998. 'Pulling the Plug on Electronic Town Meetings: Participatory Democracy and the Reality of the Usenet.' In The Politics of Cyberspace, edited by C. Toulouse and T. W. Luke. London.

Streeck, W. 2013. Buying Time: The Delayed Crisis of Democratic Capitalism, Verso.

Streeck, W. 2015. 'Comment on Wolfgang Merkel, 'Is capitalism compatible with democracy?", Zeitschrift für Vergleichende Politikwissenschaft, 9(1): 49-60.

Su, Celina. 'Beyond Inclusion: Critical Race Theory and Participatory Budgeting.' New Political Science 39.1 (2017): 126-142.

Talpin, Julien. Schools of democracy: How ordinary citizens (sometimes) become competent in participatory budgeting institutions. ECPR Press, 2012. 
Tate, C. N., Vallinder, T. 1995. The Global Expansion of Judicial Power, New York University Press.

Tereschenko, A. 2013. 'Regional Diversity and education for 'national' citizenship in Ukraine: the construction of citizenship identities by borderland youth', in D. Kiwan (ed.) Naturalization policies, education and citizenship: multicultural and multination societies in international perspective, Palgrave Macmillan.

Thaler, R.H. and C. S. Sunstein. 2008. Nudge: Improving Decisions about Health, Wealth, and Happiness. New Haven: Yale University Press.

Thaler, R.H. and C. S. Sunstein. 2008. Nudge: Improving Decisions about Health, Wealth, and Happiness. New Haven: Yale University Press.

Tierney, S. 2006. Constitutional Law and National Pluralism, Oxford University Press.

Trottier, D., \& Fuchs, C. (2014). Social media, politics and the state: protests, revolutions, riots, crime and policing in the age of Facebook, Twitter and YouTube (Vol. 16). Routledge.

US Supreme Court 2010. Citizens United v. Federal Election Commission, 08-205. Washington DC: US Supreme Court.

US Supreme Court 2014. McCutcheon v. Federal Election Commission, 12-536. Washington DC: US Supreme Court.

Van Cott, D.L. 2009. Radical democracy in the Andes, Cambridge University Press.

van den Berghe, P. 2006. 'Ethnies and Nations: Genealogy Indeed' in A. Ichijo and G. Uzelac (eds.) When is the Nation? Towards an Understanding of Theories of Nationalism, London: Routledge.

Vannucci, A. 2016. 'Corruption, neo-liberalism and democracy', IPSP.

Vauchez, A. 2005. Une institution remotivée. Le processus d'institutionnalization d'une 'nouvelle justice' en Italie (1960-2000), LGDJ. 
Vauchez, A. 2013. 'Judicialization of Politics. Lessons and Questions for the case of the French Fifth Republic', in Madsen, M. and Thornill, C. (eds.), Law and the Formation of Modern Europe, Cambridge University Press, 96-116.

Vauchez, A. 2014. Brokering Europe. Lawyers and the Making of a Transnational Polity, Cambridge University Press.

Vogel, S. 1996. Freer Markets, More Rules: Regulatory Reform in Advanced Industrialized Countries, Cornell University Press.

Welikala, A. 2015. 'Southphalia or Southfailure? National Pluralism and the State in South Asia' in S. Tierney (ed.) Nationalism and Globalization, Oxford: Hart.

Whitehead, L. 2002. Democratization: Theory and Experience, Oxford University Press.

Winickoff, David, Sheila Jasanoff, Lawrence Busch, Robin Grove-White, and Brian Wynne. 2005. 'Adjudicating the GM Food Wars: Science, Risk, and Democracy in World Trade Law.' Yale Journal of International Law 30:81-123.

Winters, J. 2011. Oligarchy, Cambridge University Press.

Wright, S. (ed.) 2008. 'Citizenship tests in a post-national era', International journal on Multicultural Societies, 10(1): 1-94.

Wynne, B. 1994. 'Public Understanding of Science.' In Handbook of Science and Technology Studies, ed. Sheila Jasanoff, Gerald Markle, James Peterson, and Trevor Pinch, 361388. Thousand Oaks, CA: Sage.

Yashar, D. 2005. Contesting Citizenship in Latin America: The Rise of Indigenous Movements and the Postliberal Challenge, Cambridge University Press.

Yiftachel, O. 2006. Ethnocracy: Land and Identity Politics in Israel/Palestine, University of Pennsylvania Press. 
Youmans, W. L., \& York, J. C. (2012). Social media and the activist toolkit: User agreements, corporate interests, and the information infrastructure of modern social movements. Journal of Communication, 62(2), 315-329. 